\title{
Adsorption of High Chromium Concentrations from Industrial Wastewater Using Different Agricultural Residuals
}

\author{
El-Baz A. A., Hendy I., Dohdoh A. M., Srour M. I. * \\ Environmental Engineering Department, Faculty of Engineering, Zagazig University, Zagazig, Sharkia 44519, Egypt \\ Received: 23/08/2020 \\ Accepted: 25/09/2020 \\ Published: 20/03/2021
}

\begin{abstract}
Hexavalent chromium $\mathrm{Cr}$ (VI) is a toxic material used in many industries such as tanneries and electroplating industries. Most of the previous researches studied the removal of chromium at lower concentrations up to $600 \mathrm{mg} / \mathrm{L}$ but did not tackle the behavior at higher concentrations, which resemble the real concentration of studied tanneries effluents. The present research is a comparative study of different agricultural low cost adsorbents in the removal of high Chromium concentration from industrial wastewater up to $1000 \mathrm{mg} / \mathrm{L}$, compared to a commercial activated carbon. The tested adsorbents are (Banana Waste (BW), Sawdust (SD), Phragmites Australis (PA), Sugarcane Bagasse (SCB), Pea pod peels (PPP) and Rice straw (RS)). The materials were chemically pretreated with acid-alkali except BW was treated with acid only, to improve adsorbent metal binding capacity. Batch experiments were conducted to study the effect of $\mathrm{pH}$, adsorbent dosage, contact time, initial Chromium concentration and temperature on the removal efficiency of Chromium from wastewater. The experiments were conducted in two sets, one for lower concentration (25-50-100-200-400) mg/L and the other for higher concentration (600-800-1000) to simulate the concentration of Chromium in tannery industry effluents. At $1000 \mathrm{mg} / \mathrm{L}$ initial concentration, BW achieved the optimum removal efficiency of $73.28 \%$ at $\mathrm{pH}=3$, adsorbent dosage $=25 \mathrm{~g} / \mathrm{L}$ and contact time of 3 hours with the adsorption capacity was $39 \mathrm{mg} / \mathrm{g}$. For SD at $\mathrm{pH}=2,3$ hours contact time, $10 \mathrm{~g} / \mathrm{L}$ dosage, and $30^{\circ} \mathrm{C}$ the removal ratio was $64.83 \%$ and the adsorption capacity was $86.30 \mathrm{mg} / \mathrm{g}$. The equilibrium data for various agricultural adsorbents was being tested with various adsorption isotherm models such as Langmuir, Freundlich and Tempkin. At low concentrations, AC, BW, PA and SCB follows Freundlich isotherm model while SD follows Langmuir isotherm model. At higher concentrations, BW, SD, PA follows Langmuir isotherm while SCB follows Tempkin isotherm model. To evaluate the mechanism of Cr adsorption on different adsorbents, Pseudofirst-order and Pseudo-second-order equations were used. The adsorption process follows Pseudo-second-order for all adsorbents, which confirms the chemisorption of $\mathrm{Cr}$ (VI) on different adsorbents.
\end{abstract}

Keywords: Chromium; adsorption; low cost adsorbents; Industrial wastewater; isotherms; kinetics; high concentrations

\section{Introduction}

A wide range of toxic inorganic and organic chemicals are discharged into the environment as industrial wastes, causing critical pollution problems (1). Water pollution caused by toxic heavy metal ions has become a serious environmental problem. A serious health hazard results from dissolved heavy metals escaping into the environment, which accumulate throughout the food chain in living tissues, multiplying their effects (2). Chromium is an important heavy metal that is released into natural water from various sources, including electronics, electroplating, metallurgical, and leather tanning industries (3) (4). It is found in nature in two different forms as trivalent chromium (Cr (III)) and hexavalent chromium (Cr (VI)) (5) (6) (7) (8). Chromium (III) is relatively insoluble and useful micronutrient for human, plants, and animals metabolism whereas chromium (VI) is primary contaminant and more toxic, carcinogenic and mutagenic to living organisms than other heavy metals (9) (7). In addition, it also has an effect on human skin, liver, kidney, and respiratory organs (10). Therefore, it is necessary to eliminate $\mathrm{Cr}$ (VI) from the environment, in order to prevent the deleterious impact of $\mathrm{Cr}$
(VI) on ecosystem and public health (4). According to WHO, the maximum allowable limits for chromium in wastewater is $1.0 \mathrm{mg} / \mathrm{L}$ while in drinking water is $0.05 \mathrm{mg} / \mathrm{L} \mathrm{(5).}$

The process of tanning using chromium compounds is one of the most common methods of processing the hides. Around $60-70 \%$ of chromium reacts with the hides in this process. In other words, about $30-40 \%$ of the chromium remains in the solid and liquid. Hence, the wastewater of tanning process is an important source of chromium pollution. In addition, it is desirable to recover chromium from the wastewater (11) (12). A number of methods are available for the removal of heavy metals from aqueous solution. These methods include chemical precipitation, ion exchange, membrane separation process, electrocoagulation and adsorption (2)(13)(7). Although the chemical precipitation has traditionally been the most used method (14), it suffers from many draw backs like incomplete removal, requirement of sizable quantities of treatment chemicals and production of large amount of toxic sludge. A variety of other treatment technologies were considered and evaluated. Techniques such as the exchange of ions and the adsorption using products from naturally occurring materials

Corresponding author: Environmental Engineering Department, Faculty of Engineering, Zagazig University, Zagazig, Sharkia 44519, Egypt, Tel./Fax: +0020552304987; Email: mohamedsrour20102005@ gmail.com. 
such as activated carbon have been considered as better alternatives. The exorbitant cost involved with ion exchange makes it prohibitive for wide application (15). Among all these methods, adsorption is the most popular since it is a very simple technique due to its convenience, ease of operation, and versatility (16) (9). This process can minimize or eliminate various types of pollutants and has therefore a wide range of applications in wastewater treatment (13)

The most common used adsorbents are nanomaterials and activated carbon as they have large surface area, adsorption capacity and microporous structure but their cost are high (9). Therefore, it is necessary to look for a cheaper and easily available alternate. Consequently, a large number of available low-cost adsorbents including agro-based material are used to remove Chromium from polluted wastewater. The most popular adsorbents prepared from agricultural wastes are Banana Waste (BW), Sawdust (SD), Sugarcane Bagasse (SCB), Phragmites Australis (PA), Pea Pod Peels (PPP) and Rice straw (RS). Many researchers seek the optimum operating parameters for each of these adsorbents including $\mathrm{pH}$, adsorbent dosage, initial concentration and contact time as well as preparation methods. (17) used $0.1 \mathrm{~N} \mathrm{NaOH}$ and $0.5 \mathrm{~N}$ $\mathrm{NaOH}$ as a chemical preparation for Banana Waste (BW) to increase its adsorption capacity. Although the $\mathrm{pH}$ is an important parameter; its effect and optimum value is a controversial topic, (18) reported that optimum removal achieved at $\mathrm{pH}$ of 1, while (19) and (20) found that optimum $\mathrm{pH}$ was at $\mathrm{pH} 3$. On the other hand; (21) concluded that the optimum $\mathrm{pH}$ was 7. Different adsorbent dosage ranges were used to find the effect of dosage on $\mathrm{Cr}$ (VI) removal. The optimum dosage was $0.4,4$ and $20 \mathrm{gm} / \mathrm{L}$ according to (18), (19) and (20). The initial concentration was studied also in a range of 1 to $70 \mathrm{mg} / \mathrm{L}$ by (18), (21) and (20) while (19) studied the effect of initial concentration at 100 to $600 \mathrm{mg} / \mathrm{L}$. The contact time also was studied from 10 minutes to 270 minutes. Finally, the effect of temperature was studied in a range from 10 to $70^{\circ} \mathrm{C}$

Different studies were applied on Sawdust for the adsorption of $\mathrm{Cr}(\mathrm{VI})$ at a $\mathrm{pH}$ range of 1 to 11 and using different dosages from 4 to $24 \mathrm{gm} / \mathrm{L}$, the examined initial concentration ranged from 5 to $500 \mathrm{mg} / \mathrm{L}$ and contact time from 10 up to 1100 minutes. The optimum removal efficiency was at lower $\mathrm{pH}$ according to (S. Gupta \& Babu, 2009, (22). (10) and (9) Whereas (23) found that the optimum removal at $\mathrm{pH}$ value of 6 after 1 hour contact time, using $1 \mathrm{~g} / \mathrm{L}$ dosage and $20 \mathrm{mg} / \mathrm{L}$ initial concentration. Many researches used raw Sugarcane bagasse (SCB) and modified Sugarcane bagasse for the adsorption of chromium from polluted water. Washed SCB with distilled water is examined at $\mathrm{pH}$ range from 1 to 7 for different time intervals at low chromium concentrations ranging from 5 to $120 \mathrm{mg} / \mathrm{L}$ (24) (25) (26) (27) (28) (2). Modifications on SCB was done through carbonization under $\mathrm{N}_{2}$ flow (29) or through chemical modification using $\mathrm{H}_{2} \mathrm{SO}_{4}$ to increase its surface area and the degree of micro porosity(30). Phragmites Australis is used as a new low cost adsorbent for the removal of COD, BOD,TSS and TDS as it is available around drains and also causes environmental problems (31). Phragmites Australis is also used in constructed wetlands to remove Chromium, Boron, Nitrogen and Phosphorous from tannery industrial wastewater because of its ability to adapt to climatic conditions. The optimum removal efficiency for $\mathrm{Cr}$ was $48 \%$ at HRT $=3$ days when the initial concentration was $0.23 \mathrm{mg} / \mathrm{L}(32)$. Biochar was produced using pyrolysis process in the presence of nitrogen gas on Green Pea Pod Peels (GPPP) to be used in $\mathrm{Cr}$ (IV) removal under different conditions(4). (4) studied the potential of using biochar from GPPP in a pH rang of (2-7), biochar dosages $(0.5-5 \mathrm{~g} / \mathrm{L})$, initial $\mathrm{Cr}$ (VI) concentrations (20-200 g/L) and contact time till $300 \mathrm{~min}$ at $30^{\circ} \mathrm{C}$. (20) used the modification of PPP with $\mathrm{NaOH}$ and $\mathrm{HCl}$ to increase the adsorptive characteristics of PPP. Many methods for modification of Rice Straw were done to increase its adsorption of heavy metals. First of all is the biochar production at different temperatures of 300,500 and $700^{\circ} \mathrm{C}$ as investigated by (3). (33) modified RS with acid treatment using nitric acid and $\mathrm{CaO}$ and alkali treatment using $\mathrm{NaOH}$ and urea. Modification with $\mathrm{NaOH}$ only is used by (34). (35) modified the rice husk with tartaric acid while (36) used $\mathrm{KOH}$ for the production of rice straw carbon (RSC) and rice straw activated carbon (RSAC). Activated Carbon (AC) is considered the best adsorbent for heavy metal because of the large internal surface area, pours availability and high microporous(37). AC is preferred for its very high surface areas, porous sorbent, functional groups, high capacity, high rate of adsorption, great capacity to adsorb a wide range of pollutants, fast kinetics and a high quality treated effluent (38). On the other hand, the main disadvantages of $\mathrm{AC}$ are its very expensive cost, requires complexing agents to improve its removal performance and its performance is dependent on the type of carbon (39) (40). Most of the previous studies gave great attention to low concentration for heavy metals $\left(5-400 \mathrm{mgL}^{-1}\right)$ and studied the effect of low cost adsorbents in the removal of such metals but they didn't study the effect of these materials on high concentration. Therefore, the main objective of this study is to investigate the effect of these materials on the removal of Chromium from low and high concentration industrial wastewater up to $1000 \mathrm{mg} / \mathrm{L}$.

\section{Material and Methods}

\subsection{Adsorbents Preparation and Treatment}

In the current study, the effectiveness of six low cost adsorbent materials in the removal of Chromium from tannery industrial wastewater compared to the efficiency of charcoal Activated Carbon (AC) was investigated. The materials are BW, SD, SCB, PA, PPP and RS. The utilized materials are solid waste that will increase environmental pollution problems if not properly disposed of. BW, PPP and SCB are collected from fruit sellers and farmhouse while SD is collected from wood workshops; RS from fields and finally PA are collected from El-Agoa canal in Zagazig city, located at the Nile Delta zone of Egypt. Each utilized material was treated as followed: (1) it was dried at sunlight for a week and then washed many times with distilled water to get rid of any dusts, impurities and inorganic materials. (2) Oven dried at $90^{\circ} \mathrm{C}$ for three days $(5 \mathrm{~h}$ daily). (3) The material was then grinded and sieved through 100 and 200 mesh (Standard Sieves Dual Manufacturing Co., USA) for uniform size distribution. (4) The powder was then washed several times with distilled water to get rid of lighter materials and other impurities. (5) The adsorbents were then used in one of three ways. First, used directly. Second, dipped in $0.1 \mathrm{~N} \mathrm{NaOH}$ for 9 hours and washed with distilled water to remove the lignin and then dried again then rinsed separately with double-distilled water two times and dipped into $0.1 \mathrm{~N}$ $\mathrm{HCl}$ for 9 hours again to remove traces of alkalinity (16). Third, dipped in HCL only for 9 hours. Finally, the treated adsorbents were thoroughly washed with double-distilled water, then dried in a desiccator and stored there.

\subsection{Preparation of Chromium Solution}

All the chemicals used are of analytical grade (AR). A stock solution of $1000 \mathrm{mg} / \mathrm{L}$ of $\mathrm{Cr}$ (VI) is prepared by dissolving $2.8287 \mathrm{~g}$ of $99.9 \%$ potassium dichromate $\left(\mathrm{K}_{2} \mathrm{Cr}_{2} \mathrm{O}_{7}\right)$ in $1000 \mathrm{ml}$ of distilled water. This solution is diluted as required to obtain standard solutions containing 25-50-100-200-400- 
600 and $800 \mathrm{mg} / \mathrm{L}$ of $\mathrm{Cr}(\mathrm{VI})$. $\mathrm{pH}$ adjustment is done using 0.5 $\mathrm{N} \mathrm{HCl}$ and $0.5 \mathrm{~N} \mathrm{NaOH}$ solutions.

\subsection{Adsorption Kinetics}

In the adsorption process, it is important to study the kinetics of the adsorption to understand and predict how time affects mobility and retention of heavy metals. In order to define the adsorption kinetics of heavy metal ions, the kinetic parameters for the adsorption process were studied at different time intervals(6). The Pseudo-first-order and Pseudo-secondorder equations are the most popular models used to describe the kinetics of Chromium adsorption. The general expression for Pseudo-first-order equation model is:

$\frac{d q_{t}}{d t}=k\left(q_{e}-q_{t}\right)$

where $\mathrm{q}_{\mathrm{e}}$ and $\mathrm{q}_{\mathrm{t}}(\mathrm{mg} / \mathrm{g})$ are the adsorption capacities at equilibrium and at any time $\mathrm{t}$ and $\mathrm{k}$ is the Pseudo-first-order rate constant $\left(\mathrm{hr}^{-1}\right)$. By applying the boundary conditions after integration of both sides from $\mathrm{t}=0$ to $\mathrm{t}=\mathrm{t}$ and $\mathrm{q}_{\mathrm{t}}=0$ to $\mathrm{q}_{\mathrm{t}}=\mathrm{q}_{\mathrm{t}}$, the linear form of the equation becomes:

$\log \left(q_{e}-q_{t}\right)=\log q_{e}-\frac{k}{2.303} t$

The values of $\mathrm{q}_{\mathrm{e}}$ and $\mathrm{k}$ at different initial concentrations are calculated from the slope and intercept of the plots of log $\left(\mathrm{q}_{\mathrm{e}}-\mathrm{q}_{\mathrm{t}}\right)$ versus $\mathrm{t}(18)$. The Pseudo-second-order chemisorption kinetic rate equation is also expressed as:

$\frac{d q_{t}}{d t}=k_{2}\left(q_{e}-q_{t}\right)^{2}$

where $\mathrm{q}_{\mathrm{e}}$ and $\mathrm{q}_{\mathrm{t}}(\mathrm{mg} / \mathrm{g})$ are the adsorption capacities at equilibrium and at any time $\mathrm{t}$ and $\mathrm{k}_{2}$ is the Pseudo-second-order rate constant $(\mathrm{g} / \mathrm{mg} / \mathrm{hr})$. By applying the boundary conditions after integration of both sides from $\mathrm{t}=0$ to $\mathrm{t}=\mathrm{t}$ and $\mathrm{q}_{\mathrm{t}}=0$ to $\mathrm{q}_{\mathrm{t}}$ $=q_{t}$, the integrated form of the equation becomes:

$\frac{\mathrm{t}}{\mathrm{q}_{\mathrm{t}}}=\frac{1}{\mathrm{k}_{2} \mathrm{q}_{\mathrm{e}}^{2}}+\frac{1}{\mathrm{q}_{\mathrm{e}}} \mathrm{t}$

The rate constant $\mathrm{k}_{2}(\mathrm{~g} / \mathrm{mg} / \mathrm{hr})$ and equilibrium adsorption capacity $\mathrm{q}_{\mathrm{e}}$ are calculated from the slope and intercept of the linear plot of $t$ (time) Vs t/q $\mathrm{q}_{\mathrm{t}}(19)$.

\subsection{Adsorption Isotherm Models}

In order to understand the distribution of the metal ions in the liquid and solid phases at equilibrium at a certain temperature, there is a need to fit the different isotherm models with the experimental data (23). The most applied isotherm models are; Langmuir, Freundlich and Tempkin models.

\subsubsection{Langmuir Isotherm Model}

Langmuir equation is based on the assumptions that maximum adsorption occurs on a saturated mono-layer of adsorbate molecules on the adsorbent surface that the energy of adsorption is constant and that there is no transmigration of adsorbate in the plane of the surface(18). The linearized form is:

$\frac{\mathrm{C}_{\mathrm{e}}}{\mathrm{q}_{\mathrm{e}}}=\frac{1}{\mathrm{~b} \mathrm{Q}_{\mathrm{m}}}+\frac{1}{\mathrm{Q}_{\mathrm{m}}} \mathrm{C}_{\mathrm{e}}$ where, $\mathrm{Q}_{\mathrm{m}}$ and $\mathrm{b}$ are Langmuir constants related to the sorption capacity (the amount of adsorbate required to form a single monolayer on unit mass of adsorbent $(\mathrm{mg} / \mathrm{g})$ ), and sorption energy which quantitatively reflects the affinity between the adsorbent and adsorbate $(\mathrm{L} / \mathrm{mg})$, respectively. $\mathrm{C}_{\mathrm{e}}$ is the equilibrium concentration in $(\mathrm{mg} / \mathrm{L})$, and $\mathrm{q}_{\mathrm{e}}$ is the amount of adsorbate adsorbed per unit weight of adsorbent $(\mathrm{mg} / \mathrm{g})$ at equilibrium (21). The plot of $\mathrm{C}_{\mathrm{e}}$ versus $\mathrm{C}_{\mathrm{e}} / \mathrm{q}_{\mathrm{e}}$ gives a linear form if the adsorption equilibrium obeys Langmuir equation. An extended analysis of the Langmuir equation can be made based on a dimensionless equilibrium parameter, $\mathrm{R}_{\mathrm{L}}$, also known as the separation factor,

$\mathrm{R}_{\mathrm{L}}=\frac{1}{1+\mathrm{bC}_{\mathrm{o}}}$

If the value of $R_{L}$ obtained between 0 and 1 , it is a favorable adsorption, while if $\mathrm{R}_{\mathrm{L}}>1$, this denotes an unfavorable adsorption, and if $\mathrm{R}_{\mathrm{L}}=1$, this represents the linear adsorption, while the adsorption operation is irreversible if $R_{L}=0$.

\subsubsection{Freundlich Isotherm Model}

The Freundlich model supposes that the adsorption of metal ions takes place on a non-ideal heterogeneous surface by multilayer adsorption. For adsorption from solution, the Freundlich isotherm is expressed in the linear form as:

$\log \mathrm{q}_{\mathrm{e}}=\log \mathrm{K}_{\mathrm{F}}+\mathrm{n}_{\mathrm{F}} \log \mathrm{C}_{\mathrm{e}}$

where, $\mathrm{K}_{\mathrm{f}}\left(\mathrm{mg}^{1-1 / \mathrm{n}} \mathrm{L}^{1 / \mathrm{n}} \mathrm{g}^{-1}\right)$ is the Freundlich constant, which indicates the relative adsorption capacity of the adsorbent; the larger its value, the higher the capacity. and $\mathrm{n}_{\mathrm{F}}$ is the adsorption intensity or the heterogeneity of the sorbent; the more heterogeneous the surface, the larger its value. and is also known as Freundlich coefficient(6). If the value of $n$ is unity, then the partition is independent of their concentration between the two phases. The value of $n$ below unit therefore indicates normal adsorption, while the value of $\mathrm{n}$ above one indicates cooperative adsorption(21).

\subsubsection{Tempkin Isotherm Model}

The Tempkin isotherm explained the nature of adsorption heterogeneous system. The Tempkin isotherm assumes that the adsorption heat linearly decreases with increasing adsorption capacity(9). The linear form of Tempkin equation is given by:

$\mathrm{q}_{\mathrm{e}}=\mathrm{B}_{\mathrm{T}} \ln \mathrm{A}_{\mathrm{T}}+\mathrm{B}_{\mathrm{T}} \ln \mathrm{C}_{\mathrm{e}}$

where, $\mathrm{B}_{\mathrm{T}}=(\mathrm{RT}) / \mathrm{b}_{\mathrm{T}}$, $\mathrm{T}$ is the absolute temperature in $\mathrm{K}$ and $\mathrm{R}$ is the universal gas constant $\left(8.314 \mathrm{~J} / \mathrm{mol} .{ }^{\circ} \mathrm{K}\right)$. The constant bT is related to the heat of adsorption $(\mathrm{J} / \mathrm{mol}), \mathrm{A}_{\mathrm{T}}$ is the equilibrium binding constant $(\mathrm{L} / \mathrm{g})$ corresponding to the maximum binding energy. Most of the previous studies are limited to the removal of low initial $\mathrm{Cr}$ concentrations $(5-600 \mathrm{mg} / \mathrm{L})$. The main objective of the present study is to examine the adsorption capacity of different low cost agricultural waste materials at high $\mathrm{Cr}$ concentrations $(600-1000 \mathrm{mg} / \mathrm{L})$. The above review illustrated that there are many different methods for absorbent preparation. Moreover, extensive studies concerning the operating parameters are recommended. In the present study the optimum operating parameters (including $\mathrm{pH}$, adsorbent dosage, initial concentration and contact time as well as preparation methods) for the six different adsorbents (BW, SD, SCB, PA, PPP and RS) will be assessed. Activated Carbon will be examined as standard and reference adsorbent. 


\subsection{Batch Experiments}

The batch experiments were conducted in $50 \mathrm{ml}$ conical flasks. The amount of adsorbent was added in $20 \mathrm{ml}$ of aqueous Cr (VI) solutions, and then mixed in water bath mechanical shaker at $30^{\circ} \mathrm{C}$. The treated solution is finally filtered before analysis. The main investigated parameters are in Table (1).

The high concentration range was studied in a range of 600 to $1000 \mathrm{mg} / \mathrm{L}$ based on the characterization of real samples from El-Robiekey factories for tanning in Badr city-Egypt and Quesna tanneries in Quesna city-Egypt, which ranged from 560 to $970 \mathrm{mg} / \mathrm{L}$

\subsection{Instruments}

All measurements were conducted according to standard methods. The concentration of Chromium ions in the influent as well as the effluent was measured using Atomic Absorption Spectrophotometer (ThermoFisher-iCE 3000 series) model with air -acetylene gas and wave length of $357.9 \mathrm{~nm}$ in the faculty of Agriculture central laboratory- Zagazig University, Egypt.

\section{Results and Discussion}

Using observations of the sorption studies to optimize the $\mathrm{pH}$, adsorbent dosage, initial chromium concentration, contact time, and temperature have been plotted to determine the feasibility of sorption system along with its mechanisms through kinetics. The results of batch studies were compared for different adsorbents used in the study. The effect of treatment method for materials also have been studied.

\subsection{Effect of Adsorbent Preparation Methods and Treatment}

Figure (1) shows the effect of preparation methods on the sorption efficiency. The experiments were performed at $\mathrm{pH} 3$, $50 \mathrm{mg} / \mathrm{L}$ initial concentration, $1 \mathrm{hr}$ contact time, $5 \mathrm{~g} / \mathrm{L}$ adsorbent dosage and $30{ }^{\circ} \mathrm{C}$. The results indicated that the chemical treatment of the adsorbent using $\mathrm{NaOH}$ followed by $\mathrm{HCl}$ achieved higher removal efficiency. BW was the only adsorbent that shows higher efficiency when treated with HCL only.

Table 1: Various parameters considered during batch experimental study.

\begin{tabular}{|c|c|c|c|c|c|c|}
\hline & Parameter & $\begin{array}{c}\text { Initial } \mathrm{Cr}(\mathrm{VI}) \\
\text { concentration } \\
(\mathrm{mg} / \mathrm{L})\end{array}$ & $\begin{array}{c}\text { Adsorbent } \\
\text { dosage }(\mathrm{g} / \mathrm{L})\end{array}$ & $\begin{array}{c}\text { Contact } \\
\text { time (hr) }\end{array}$ & pH & Temperature $\left({ }^{\circ} \mathrm{C}\right)$ \\
\hline \multirow{4}{*}{ 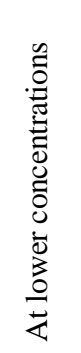 } & $\begin{array}{l}\text { Initial } \mathrm{Cr}(\mathrm{VI}) \\
\text { concentration }\end{array}$ & $25-400$ & 5 & 1 & 3 & 30 \\
\hline & Adsorbent dosage & 50 & $2-20$ & 1 & 3 & 30 \\
\hline & Contact time & 50 & 5 & $1-5$ & 3 & 30 \\
\hline & $\mathrm{pH}$ & 50 & 5 & 1 & $1-6$ & 30 \\
\hline \multirow{2}{*}{ 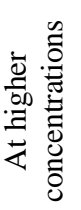 } & $\begin{array}{l}\text { Initial } \mathrm{Cr}(\mathrm{VI}) \\
\text { concentration }\end{array}$ & $600-1000$ & optimum & optimum & optimum & 30 \\
\hline & Temperature & 1000 & optimum & optimum & optimum & $30-70$ \\
\hline
\end{tabular}

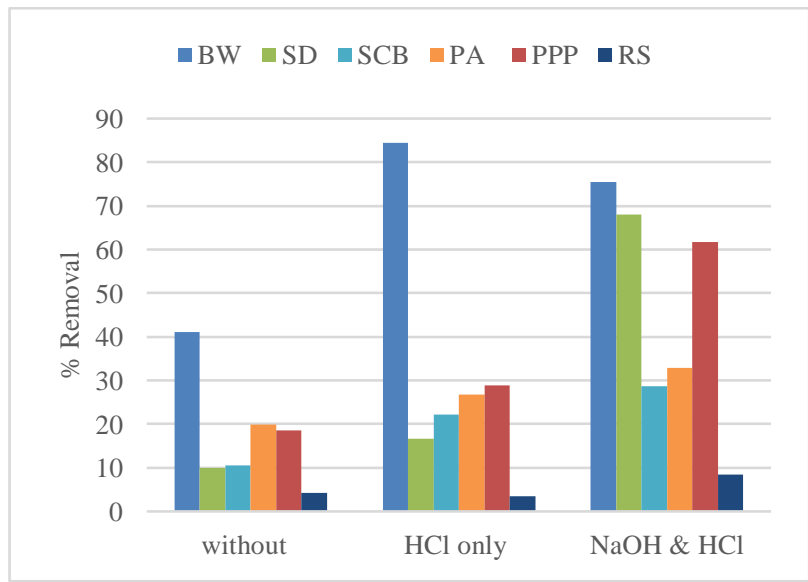

Figure 1: Effect of adsorbent preparation methods

\subsection{Effect of pH on Cr adsorption}

The $\mathrm{pH}$ of a solution is regarded as a significant parameter in the adsorption of $\mathrm{Cr}$ ions. The effect of $\mathrm{pH}$ on the efficiency of the different adsorbents compared to the activated carbon were investigated at the following conditions initial concentration $=50 \mathrm{mg} / \mathrm{L}$, dosage $=5 \mathrm{~g} / \mathrm{L}, 30^{\circ} \mathrm{C}$ and contact time $1 \mathrm{hr}$. The results revealed that $\mathrm{Cr}$ ions adsorption by the materials were highly pH-dependent as shown in Figure (2). Each material has its own behavior at different $\mathrm{pH}$ values, most of the examined material show high removal at low $\mathrm{pH} 2$ to 3 . $\mathrm{BW}$ as well as AC achieved its optimum efficiency at $\mathrm{pH} 3$. It was evident that the most prevalent form of $\mathrm{Cr}(\mathrm{VI})$ in aqueous solution was acid chromate $\left(\mathrm{HCrO}_{4}^{-}\right)$, chromate $\left(\mathrm{CrO}_{4}^{-2}\right)$, dichromate $\left(\mathrm{Cr}_{2} \mathrm{O}_{7}^{-2}\right)$ and other oxyanions of $\mathrm{Cr}$. The dominant form of $\mathrm{Cr}(\mathrm{VI})$ at initial $\mathrm{pH}$ of 2 is acid chromate $\left(\mathrm{HCrO}_{4}{ }^{-1}\right)$. Increase in $\mathrm{pH}$ facilitates the conversion of $\mathrm{HCrO}_{4}{ }^{-1}$ to other forms, $\mathrm{CrO}_{4}^{-2}$ and $\mathrm{Cr}_{2} \mathrm{O}_{7}^{-2}$. At lower $\mathrm{pH}$, the adsorbent has a positive charge because of protonation, and dichromate ion exists as anion and the electrostatic forces developed between 
them, resulting in a high adsorption at lower $\mathrm{pH}$. The removal efficiency of $\mathrm{Cr}$ (VI) reduced significantly at higher $\mathrm{pH}$ due to the competition between $\mathrm{OH}^{-}$and chromate ions $\left(\mathrm{CrO}_{4}^{-2}\right)$, where the former being the dominant species reach the adsorbent surface more quickly than chromium species (18)(41)(42). It is well-known fact that the surface adsorbs anions favorably in low $\mathrm{pH}$ range due the presence of $\mathrm{H}^{+}$ions, whereas the surface is active for the adsorption of cations at higher $\mathrm{pH}$ values due to the accumulation of $\left(\mathrm{OH}^{-}\right)$ions (16). The highest value obtained was $82.83 \%$ for sawdust at $\mathrm{pH}=2$. Similar observations for best removal efficiency were reported by (19) at $\mathrm{pH}=3$, (9) at $\mathrm{pH}=$ 2 and (7) at $\mathrm{pH}=3$.

\subsection{Effect of Adsorbent Dosage on Cr Adsorption}

As shown in Figure (3-a), the percentage chromium removal is directly proportional to adsorbent dose. The effect of adsorbent dosage was studied at $\mathrm{pH}=3$, contact time $=1 \mathrm{hr}$, initial chromium concentration of $50 \mathrm{mg} / \mathrm{L}$ and at $30{ }^{\circ} \mathrm{C}$. Using $5 \mathrm{~g} / \mathrm{L}$ of BW is sufficient to adsorb about $80 \% \mathrm{Cr}$ (VI) having $50 \mathrm{mg} / \mathrm{L}$ initial concentration within $1.0 \mathrm{~h}$. On further increasing, the adsorbent dose to $20 \mathrm{~g} / \mathrm{L}$ the removal efficiency was observed to be almost constant. This may be due to some of the adsorption sites remaining unsaturated during the adsorption process. The increase in the adsorbent dosage provides more exchangeable sites or surface area of the adsorbent. Interference among binding sites owing to increased adsorbent dosage cannot be ruled out as this will result in low specific uptake (31).

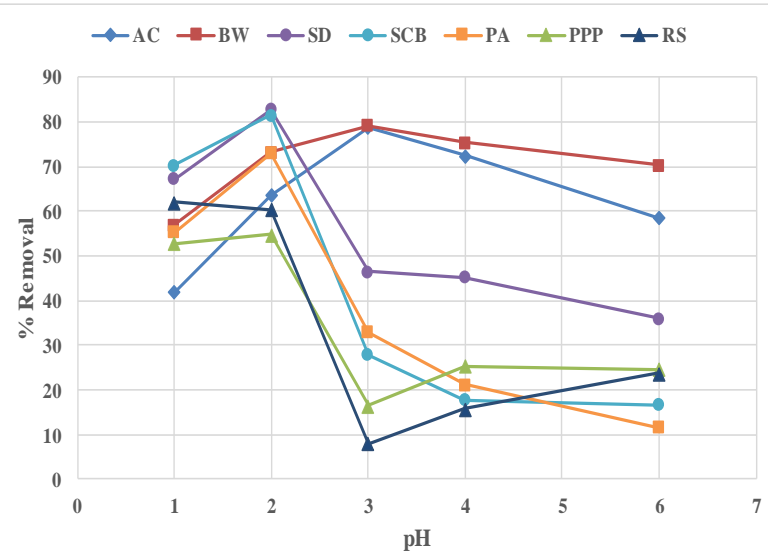

Figure 2: Effect of $\mathrm{pH}$ on $\mathrm{Cr}$ adsorption efficiency

Similarly, $20 \mathrm{~g} / \mathrm{L}$ adsorbent dose of sawdust adsorbs more than $60 \%$ at $\mathrm{pH} 3.0$; Phragmites Australis adsorbs more than $45 \%$ at $\mathrm{pH}$ 3.0. Matching trends were also reported by (6), (43) and (2) (44) (26). The increase in Cr (VI) removal with increase in adsorbents amount is due to the increase in surface area and adsorption sites available for adsorption. In contrast, the amount adsorbed for unit mass of adsorbents decreases as the dose of adsorbent increases (Fig. 3-b). At low adsorbent dose, all active adsorbent sites are completely exposed and occupied by the $\mathrm{Cr}(\mathrm{VI})$, which is excessive, saturating the surface and yielding the higher $\mathrm{q}_{\mathrm{e}}$, while the decrease in unit adsorption with increased adsorbent dose is mainly due to the unsaturation of adsorption sites during the adsorption phase. The maximum adsorption capacity was $17.6 \mathrm{mg} / \mathrm{g}$ achieved by using BW compared to $21 \mathrm{mg} / \mathrm{g}$ for $\mathrm{AC}$ at $2 \mathrm{~g} / \mathrm{L}$ dosage. Similar trend was reported by (4), (6) and (45).

\subsection{Effect of Contact Time on Cr Adsorption}

The effect of contact time on $\mathrm{Cr}$ adsorption on the different materials is important to define the time required for $\mathrm{Cr}$ (VI) to reach an equilibrium when put in contact with the different adsorbents. Fig. (4) Shows the percentage removal of $\mathrm{Cr}$ for different value of contact time ranging from 1 to 5 hours at $\mathrm{pH}$ 3 , Cr initial concentration $=50 \mathrm{mg} / \mathrm{L}$, adsorbent dosage of $5 \mathrm{~g} / \mathrm{L}$ and $30^{\circ} \mathrm{C}$ temperature. Fig. (4) Indicated that increasing the contact time from 1 to 3 hours, increased the percentage removal, because of the large number of active sites available for adsorption and high rate of adsorption at first. After that, the percentage removal of $\mathrm{Cr}$ reaches slowly to higher values or remains constant as the active sites is about to be saturated. Hence, the equilibrium time obtained is 3 hours for the $\mathrm{Cr}$ adsorption on all adsorbents except for PPP and RS as they gave unsatisfying results so they we refused in further experiments for higher concentrations. These results agree with the trends of (31), (45), (46) and (47). The optimum Chromium removal percentage obtained at 3 hours equilibrium time was for BW with $80.91 \%$ at $\mathrm{pH}=3$ and $10 \mathrm{~g} / \mathrm{L}$ dosage followed by $73.79 \%$ for SD at the same conditions.

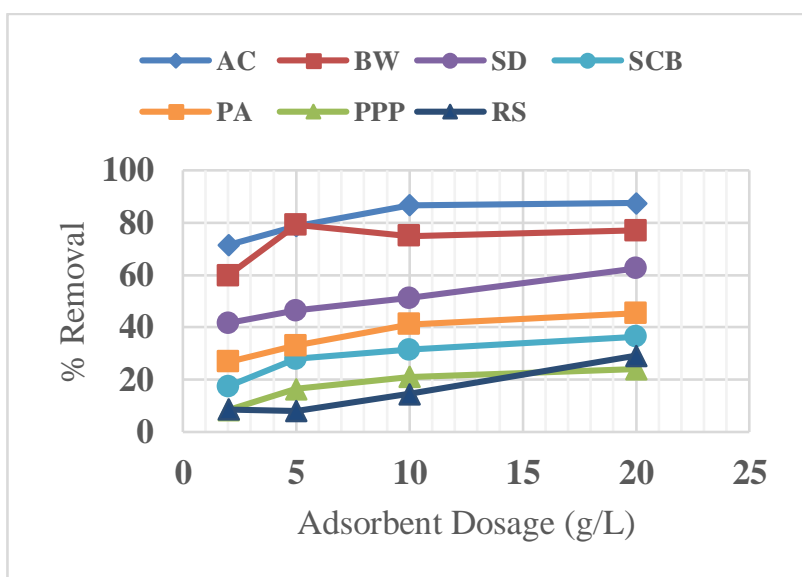

Figure 3-a: Effect of adsorbent dosage on $\mathrm{Cr}$ adsorption efficiency

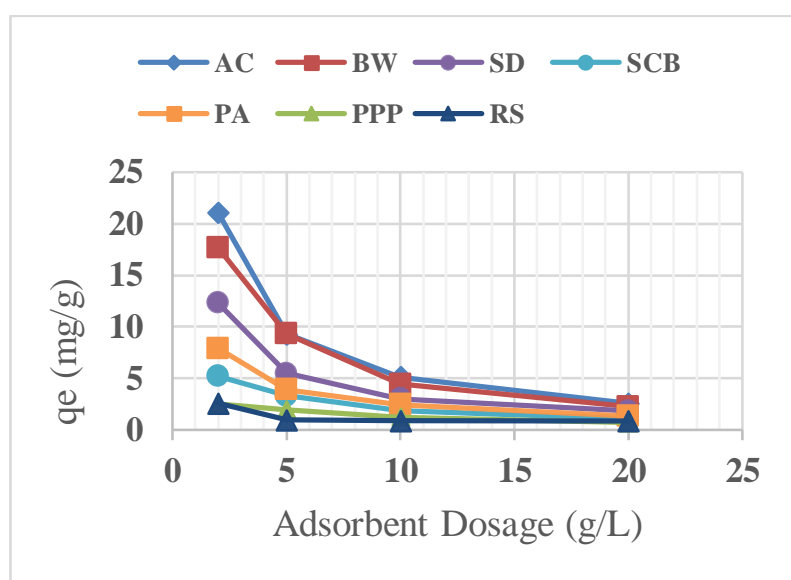

Figure 3-b: Effect of adsorbent dosage on adsorption Capacity $\left(\mathrm{q}_{\mathrm{e}}\right)$

\subsection{Effect of initial concentration on Cr adsorption}

$\mathrm{Cr}$ (VI) adsorption is greatly affected by the initial concentration of $\mathrm{Cr}$ (VI) in aqueous solutions. In the present study, the adsorption experiments were performed to study the effect of initial $\mathrm{Cr}$ (VI) concentration at the following conditions: dosage amount $5 \mathrm{~g} / \mathrm{L}, \mathrm{pH}=3$, contact time $=1 \mathrm{hr}$ and at $30^{\circ} \mathrm{C}$. Fig. (5-a) shows the effect of initial concentration at low values ranged from 25 to $400 \mathrm{mg} / \mathrm{L}$. The results show that with increase in $\mathrm{Cr}$ (VI) concentration from 25 to $400 \mathrm{mg} / \mathrm{L}$, the percentage removal decreases and adsorption capacity increases. 


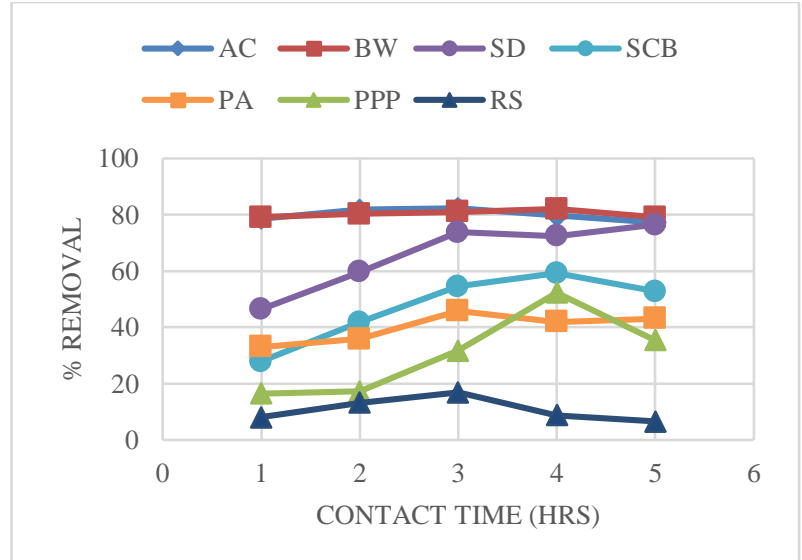

Figure 4: Effect of contact time on Cr adsorption efficiency

The decrease in percentage removal can be illustrated by the fact that all the adsorbents had a fixed number of active sites, which would have become saturated above a certain concentration. The increase in adsorption capacity with increase in $\mathrm{Cr}$ (VI) concentration as shown in Fig. (5-b) may be due to the higher adsorption rate and utilization of all active sites available for the adsorption at higher concentration. Banana waste achieved the optimum removal efficiency of about $84 \%$ at Chromium initial concentration of $25 \mathrm{mg} / \mathrm{L}$ followed by sawdust with removal efficiency of about $76 \%$ then by Phragmites Australis and sugarcane bagasse with removal efficiency of $48 \%$. These results match the trend of (6), (2), (34), (4), (48) and (45). At the highest concentration of 200 $\mathrm{mg} / \mathrm{L}$, BW registered the optimum removal efficiency of $60.2 \%$.

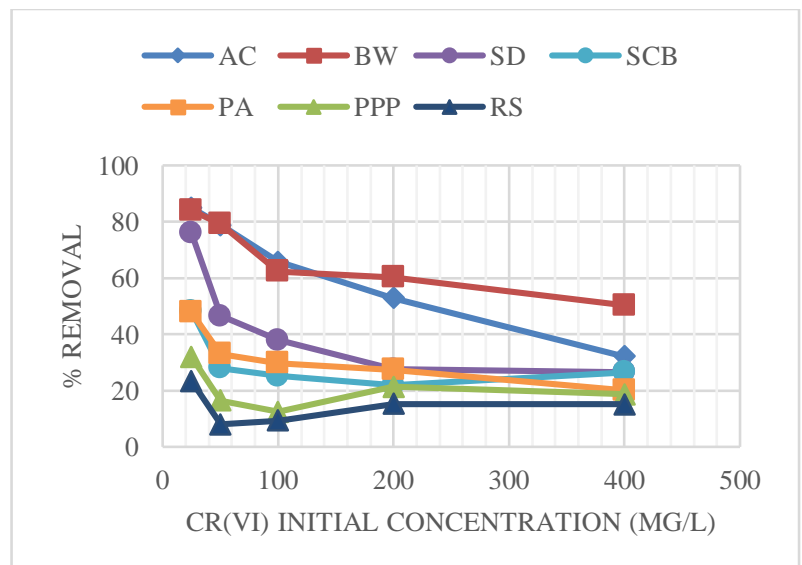

Figure 5-a: Effect of $\mathrm{Cr}$ initial concentration on adsorption efficiency

\subsection{Effect of high initial concentration on Cr adsorption}

The four absorbents achieved higher removal efficiency at $400 \mathrm{mg} / \mathrm{L}$ initial concentration (Banana waste (BW), Sawdust (SD), Phragmites Australis (PA) and sugarcane bagasse (SCB)) will be investigated at higher concentration of 600,800 and $1000 \mathrm{mg} / \mathrm{L}$. Figures (6-a), (6-b), (6-c) and (6-d) show the removal efficiencies of the examined adsorbent at high concentrations and their capacities in $\mathrm{mg} / \mathrm{g}$. The adsorbents were examined at different three dosages $(10-20-25) \mathrm{gm} / \mathrm{L}$. The optimum $\mathrm{pH}$ for $\mathrm{BW}$ was 3 , while it was 2 for the rest and the contact time was 3 hours for all experiments. Fig. (6-a) shows the performance of $\mathrm{BW}$ at high concentrations, the dosages changed from 10 to 20 and then $25 \mathrm{gm} / \mathrm{L}$. The optimum removal at $600 \mathrm{mg} / \mathrm{L}$ was $77.8 \%$ which was decreased to $75.2 \%$ at $800 \mathrm{mg} / \mathrm{L}$ and finally reached $73.3 \%$ at $1000 \mathrm{mg} / \mathrm{L}$ using 25 $\mathrm{g} / \mathrm{L}$ dosage. The decrease in removal efficiency by increasing the initial concentration was due to the occupation of the active sites of adsorbent at higher concentrations.

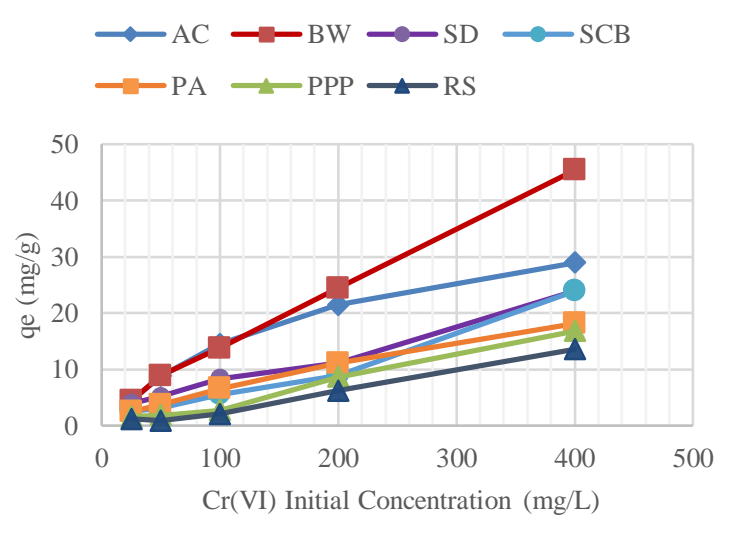

Figure 5-b: Effect of $\mathrm{Cr}$ initial concentration on adsorption Capacity

These results agree with (19) results on Grafted Banana Peels(GBP) which study the $\mathrm{Cr}$ (VI) for concentration from 100 to $600 \mathrm{mg} / \mathrm{L}$. However, the adsorption capacity increased by increasing the initial concentration and decreasing the dosage because at higher concentrations the rate of adsorption increased and increasing the dosage from $10 \mathrm{gm} / \mathrm{L}$ to $20 \mathrm{gm} / \mathrm{L}$ reduces the capacity from about 70 to $40 \mathrm{mg} / \mathrm{g}$. As the dosage decreased, it absorbs most of the $\mathrm{Cr}$ (VI) found but increasing the amount of adsorbents about some level can leads to overlapping of adsorbent particles, which make it unsaturated. The optimum removal efficiency at initial concentration of 600 $\mathrm{mg} / \mathrm{L}$ was $77.8 \%$ for $(\mathrm{BW})$ at $\mathrm{pH}=3,25 \mathrm{gm} / \mathrm{L}$ dosage. The adsorption capacity of $86.3 \mathrm{mg} / \mathrm{g}$ for SD using $10 \mathrm{gm} / \mathrm{l}$ dosage at $1000 \mathrm{mg} / \mathrm{L} \mathrm{Cr}$ concentration is the maximum value found followed by $74.78 \mathrm{mg} / \mathrm{g}$ for $\mathrm{BW}$ of $10 \mathrm{gm} / \mathrm{L}$ dosage at 1000 $\mathrm{mg} / \mathrm{L}$ concentration. The maximum adsorption capacity reported by (6) at $400 \mathrm{mg} / \mathrm{L}$ initial $\mathrm{Cr}$ (VI) concentration was $41.45 \mathrm{mg} / \mathrm{g}$. The high adsorption capacity for BW and SD at higher concentration is due to the active functional groups on their surface and high fixed carbon content. Carboxylic ($\mathrm{COOH})$ at about (3400-3650) $\mathrm{cm}^{-1}$, carbonyl at about (1670$1780) \mathrm{cm}^{-1}$ and hydroxyl (-OH) groups at about (1429-1639) $\mathrm{cm}^{-1}$ are the most common found groups on agricultural waste surface which are responsible for binding $\mathrm{Cr}(\mathrm{VI})$ from aqueous solution as shown in Fig. (7) and (8) for BW and SD from literature respectively (13). BW contains about $65 \%$ of fixed carbon which enhance its $\mathrm{Cr}(\mathrm{VI})$ adsorption capacity(49). Scanning electron microscopy (SEM) is also a measure for surface morphology of an adsorbent which can be an indication for the surface area and pores size of it. The surface of adsorbent before adsorption showed irregular heterogeneous structure which became flattened after adsorption as a result of metal ion adsorption. Fig (9) and (10) shows the SEM for BW and raw sawdust (R-SD) and modified sawdust (MSD) from literature.

\subsection{Effect of Temperature on Cr Adsorption}

The effect of temperature on Chromium adsorption was tested on the four adsorbent achieved high efficiency. The $\mathrm{pH}$, dosage and contact time for $\mathrm{BW}, \mathrm{SD}, \mathrm{SCB}$ and PA were 3,2,2,2 and 25,10,10,10 gm/1 and 3,5,5,3 hours respectively. The initial concentration was maintained constant at $1000 \mathrm{ppm}$. As shown in Fig. (7), it is observed that the percentage removal of 
Chromium increases by increasing the temperature from 30 to $70^{\circ} \mathrm{C}$ for all materials. This increase is due to the increase of the rate of adsorption at higher temperature which indicates that the adsorption process is endothermic(50). The optimum removal was for sawdust at $70^{\circ} \mathrm{C}$ by $82 \%$ followed $80.7 \%$ for banana waste at $60^{\circ} \mathrm{C}$. Similar results were reported by (20), (6) and (27).
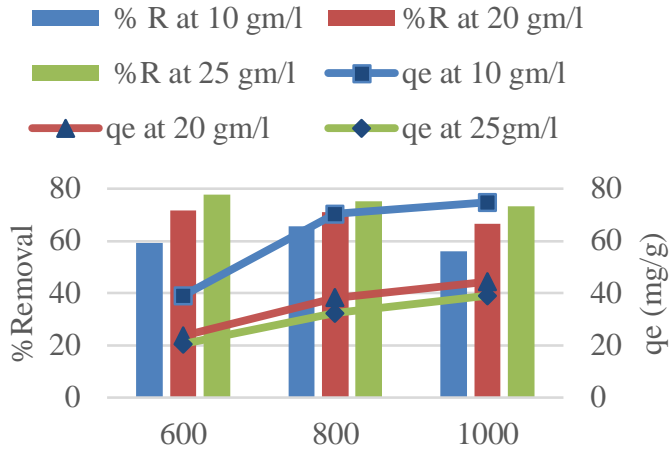

Initial Concentration $(\mathrm{mg} / \mathrm{L})$

Figure 6-a: performance of BW at high $\mathrm{Cr}$ concentrations

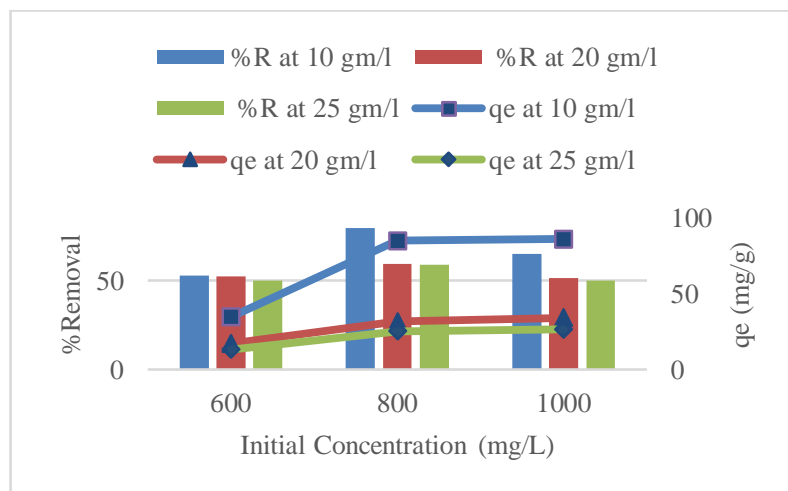

Figure 6-b: Performance of SD at high Cr concentrations

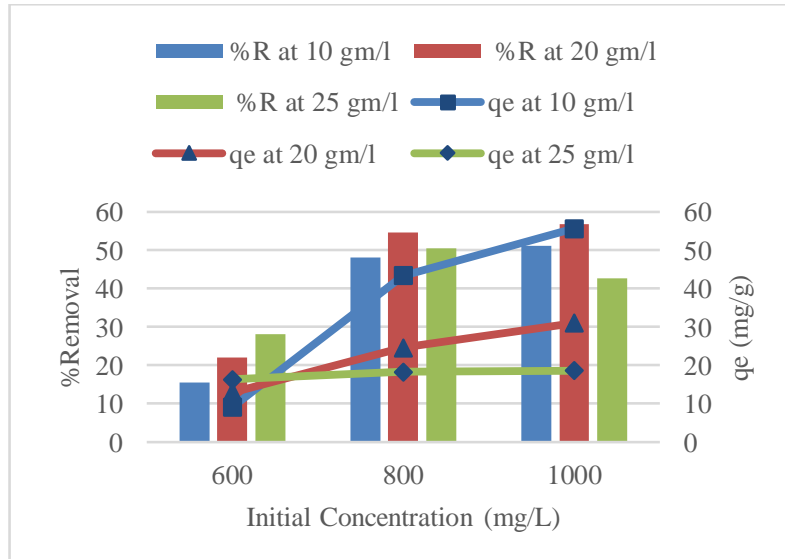

Figure 6-c: Performance of PA at high $\mathrm{Cr}$ concentrations

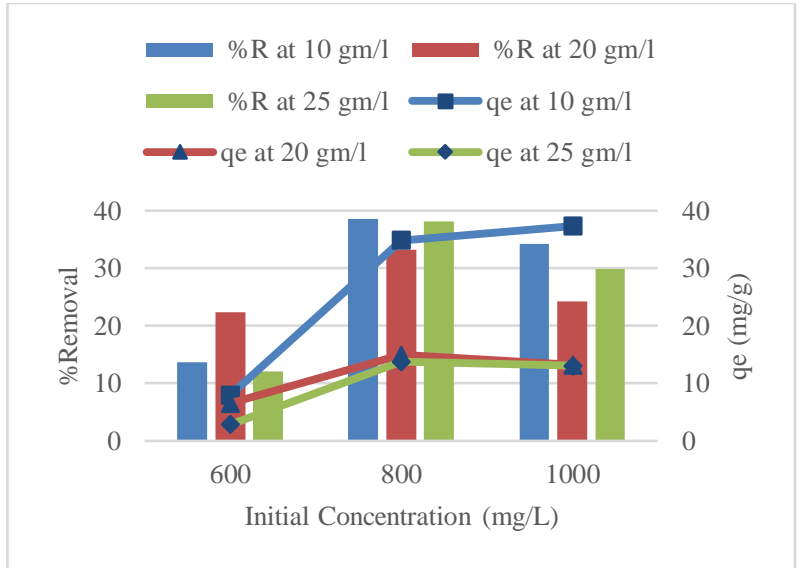

Figure 6-d: Performance of SCB at high Cr concentrations
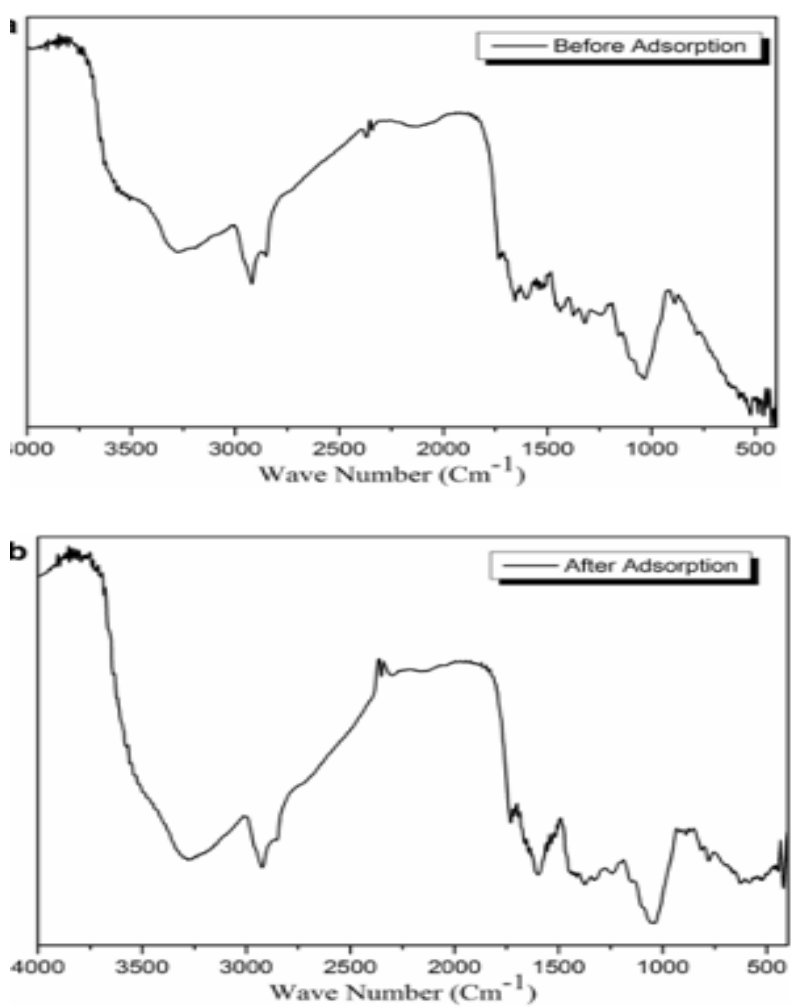

Figure 7: FTIR spectrum of banana peel dust [before and after $\mathrm{Cr}(\mathrm{VI})$ adsorption] (18)

\subsection{Adsorption Kinetics}

In order to understand the kinetic behavior of the adsorption process for $\mathrm{Cr}$ (VI) removal using the four tested materials at high concentration (BW, SD, PA and $\mathrm{SCB}$ ) compared with that of AC, the Pseudo-first- order and Pseudosecond- order models are considered to fit the kinetic experimental data. The different parameters of the two models are calculated and tabulated in Table (2). 

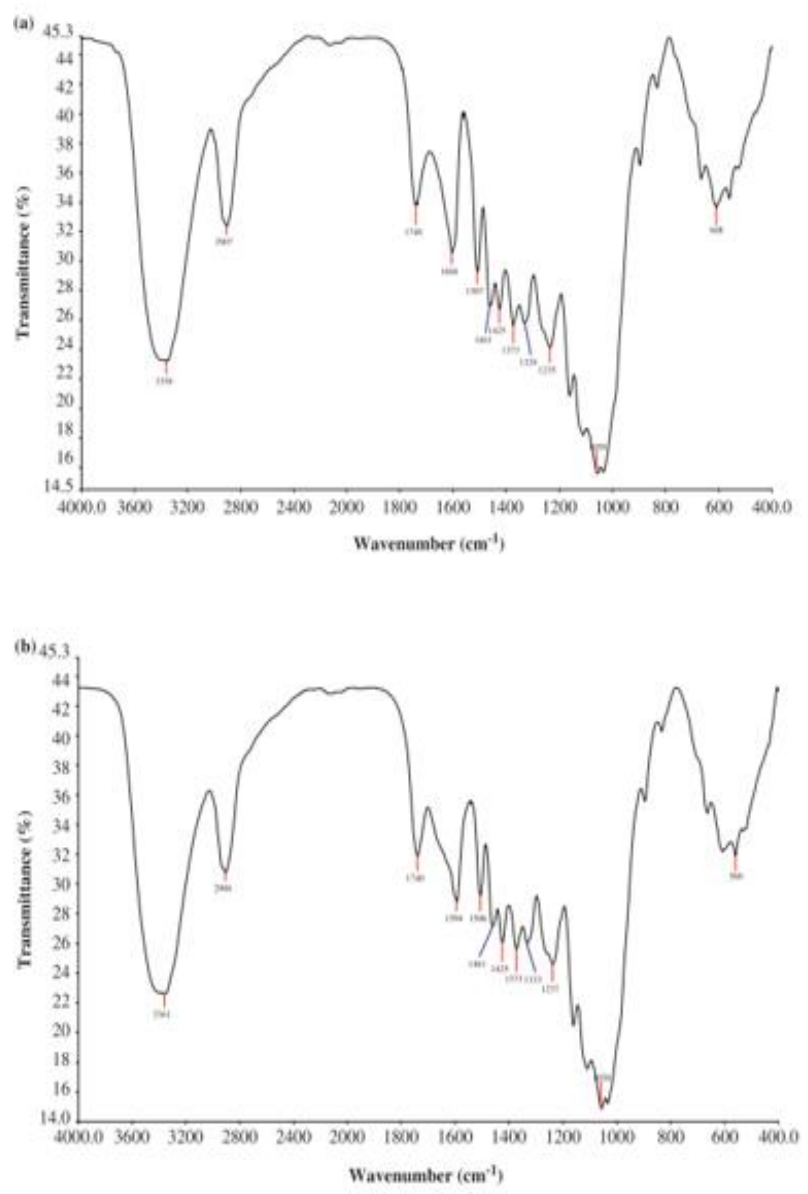

Figure 8: FTIR spectrum of sawdust [before and after $\mathrm{Cr}(\mathrm{VI})$ adsorption] (22)

\subsubsection{Pseudo-first-order Kinetic Model}

The applicability of the Pseudo-first- order kinetic model to the experimental data are tested by plotting the linear form as a graph of $\log \left(\mathrm{q}_{\mathrm{e}}-\mathrm{q}_{\mathrm{t}}\right)$ versus time Fig (8). The estimated values of the Pseudo-first- order kinetic parameters, $\mathrm{K}$ and $\mathrm{q}_{\mathrm{e}}$ along with the regression coefficient $\left(\mathrm{R}^{2}\right)$ are in Table (2). The values of $\left(\mathrm{R}^{2}\right)$ are estimated as $0.9712,0.9975,0.7865,0.9911$ and 0.6318 for the removal of $\mathrm{Cr}$ (VI) using $\mathrm{AC}, \mathrm{BW}, \mathrm{SD}, \mathrm{PA}$ and SCB respectively. These values indicate the non-agreement of the Pseudo-first- order kinetic model to the experimental data. The experimental value of the adsorption capacities at equilibrium are $9.05,9.02,8.41,5.04$ and $6.52 \mathrm{mg} / \mathrm{g}$ respectively. The predicted values of adsorption capacities using the Pseudo-first- order kinetic model are 8.26, 0.51, 6.76, 2.24 and $3.83 \mathrm{mg} / \mathrm{g}$ respectively. This disagreement between the experimental and predicted adsorption capacities confirms that the Pseudo-first-order kinetic model cannot explain the behavior of $\mathrm{Cr}(\mathrm{VI})$ adsorption on the different types of used adsorbents.

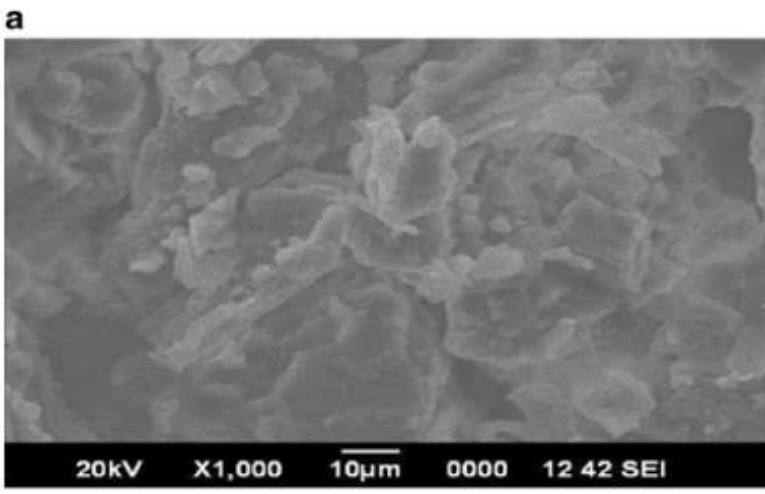

b

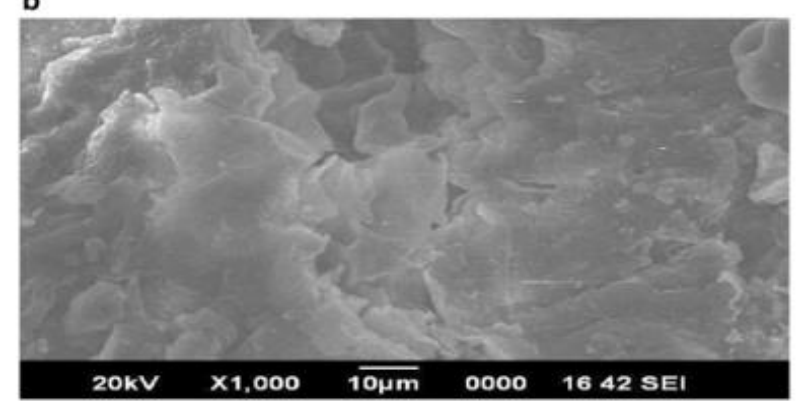

Figure 9: SEM for banana peel (a-before adsorption and b-after adsorption) (18)

\subsubsection{Pseudo-second-order Kinetic Model}

The kinetic experimental data are also fitted with the Pseudo-second- order kinetic model. The second order kinetic parameters, $\mathrm{K}_{2}$ and $\mathrm{q}_{\mathrm{e}}$ are calculated for different adsorbents using the slope and intercept of the graph of the linear form between $t / \mathrm{q}_{\mathrm{t}}$ versus time as shown in Fig. (9). The obtained values of $\mathrm{K}_{2}$ and $\mathrm{q}_{\mathrm{e}}$ and $\left(\mathrm{R}^{2}\right)$ for $\mathrm{Cr}(\mathrm{VI})$ adsorption using different adsorbents are given in Table (2). The predicted equilibrium adsorption capacities are close to that obtained from the experimental data. The value of $\mathrm{K}_{2}$ are found to be less than 1 which suggests the higher rate of adsorption at initial stage and further decrease with the lapse of time. High values of $\mathrm{R}^{2}(0.9977,0.9986,0.9924,0.9837$ and 0.9352$)$ obtained for the removal of $\mathrm{Cr}$ (VI) using $\mathrm{AC}, \mathrm{BW}, \mathrm{SD}, \mathrm{PA}$ and $\mathrm{SCB}$ respectively, show the agreement between the experimental data and the second order kinetic model.

The predicted values of adsorption capacities using the Pseudo-second- order kinetic model are 8.47, 8.79, 10.05, 5.21 and $7.97 \mathrm{mg} / \mathrm{g}$ respectively, which matches the experimental values of adsorption capacities for the mentioned adsorbents. This confirms the applicability of the Pseudo-second- order kinetic model to fit the experimental data and confirms the chemisorption of $\mathrm{Cr}$ (VI) on the adsorbents during the adsorption process. In chemisorption (chemical adsorption), the Chromium sticks to the adsorbent surface by forming a chemical bond (usually covalent) and tend to find sites that maximize their coordination number with the surface (44). These results agree with most of the previous studies on adsorbents like, (6), (20), (18), (19), (31), (9) and (22). 

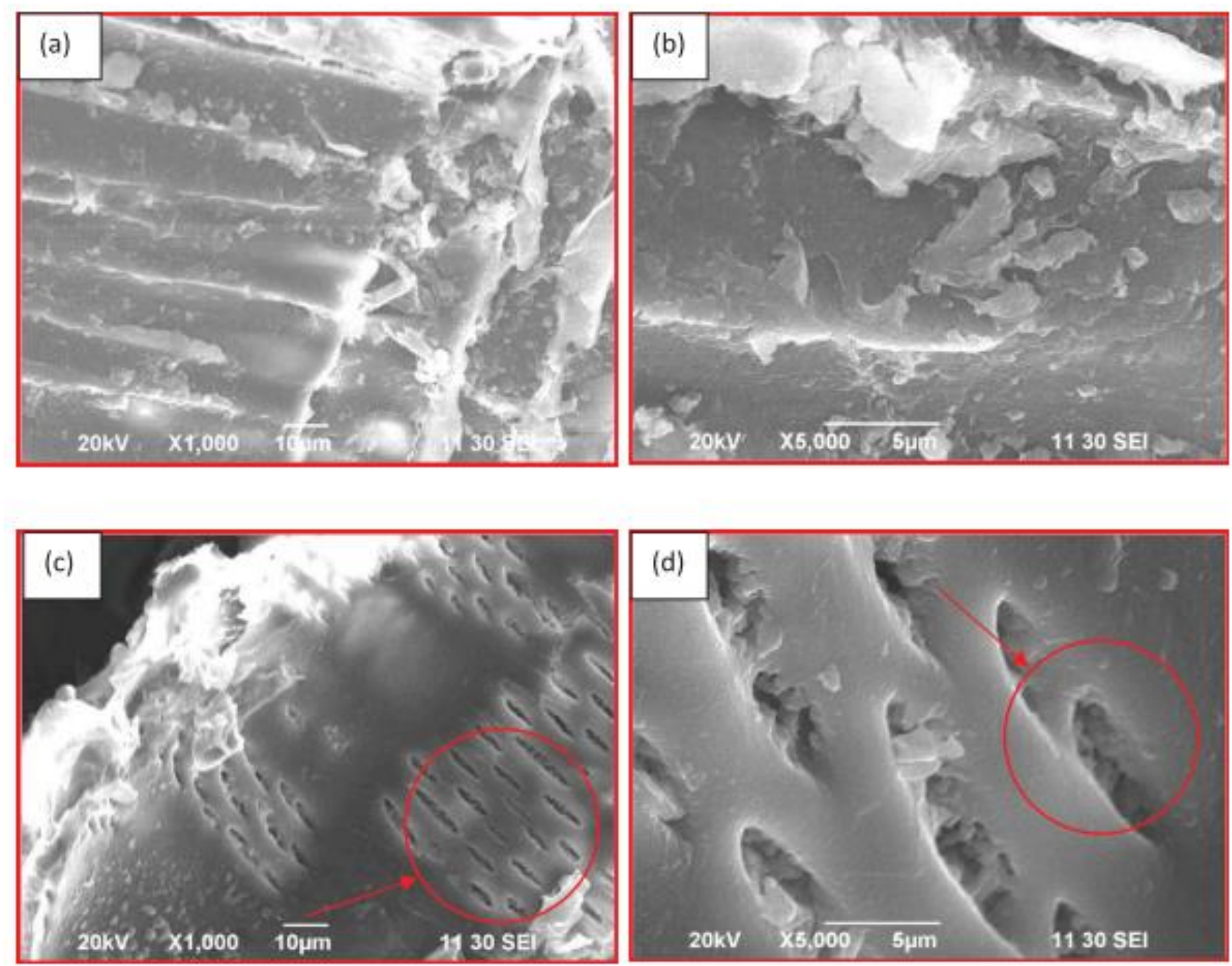

Figure 10: SEM images of (a) R-SD at 1000 magnification, (b) R-SD at 5000 magnification (c) MSD at 1000 magnification, and (d) MSD at 5000 magnification (9)

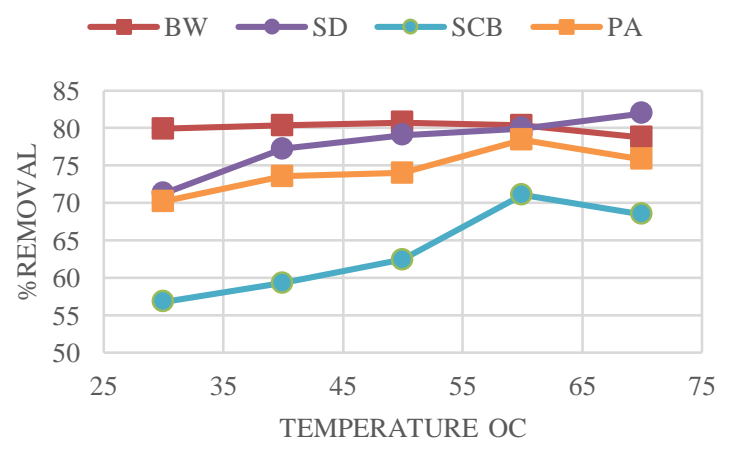

Figure 7: Effect of temperature on $\mathrm{Cr}$ adsorption efficiency

\subsection{Adsorption Isotherm Study}

An adsorption isotherm is characterized by certain constants that express the surface properties and the affinity of the adsorbent towards $\mathrm{Cr}$ (VI) adsorption (51). The equilibrium data for the adsorption of Cr (VI) using these adsorbents fits into various isotherm models which results in a suitable model that can be used for the design of an adsorption process. The most used isotherm models in adsorption process are Langmuir, Freundlich and Tempkin isotherm models. Therefore, in the present work, Langmuir, Freundlich and Tempkin isotherm models for different adsorbents are considered and are discussed in the following sections. The various isotherm parameters are estimated and tabulated in Table (3), (4) and (5) respectively.

Table 2: the kinetic constants for $\mathrm{Cr}$ removal using different adsorbents

\begin{tabular}{|c|c|c|c|c|c|c|c|}
\hline $\begin{array}{l}\text { Equation- } \\
\text { Material }\end{array}$ & \multicolumn{3}{|c|}{ Pseudo-first-order } & \multicolumn{3}{|c|}{ Pseudo-second-order } & \multirow{2}{*}{$\begin{array}{l}\text { Qe (exp.) } \\
(\mathrm{mg} / \mathrm{g})\end{array}$} \\
\hline Parameter & $\mathrm{K}\left(\mathrm{hr}^{-1}\right)$ & $\mathrm{R}^{2}$ & $\mathrm{q}_{\mathrm{e}}(\mathrm{cal}).(\mathrm{mg} / \mathrm{g})$ & $\mathrm{K}_{2}(\mathrm{~g} / \mathrm{mg} \cdot \mathrm{hr})$ & $\mathrm{R}^{2}$ & $\mathrm{q}_{\mathrm{e}}(\mathrm{cal}).(\mathrm{mg} / \mathrm{g})$ & \\
\hline Activated Carbon (AC) & 2.76 & 0.9712 & 8.26 & 1.24 & 0.9977 & 8.473 & 9.05 \\
\hline Banana waste (BW) & 0.481 & 0.9975 & 0.51 & 6.12 & 0.9987 & 8.798 & 9.02 \\
\hline Sawdust (SD) & 0.787 & 0.7866 & 6.76 & 0.104 & 0.9924 & 10.05 & 8.41 \\
\hline Phragmites Australis (PA) & 0.404 & 0.9911 & 2.24 & 0.435 & 0.9837 & 5.21 & 5.04 \\
\hline Sugarcane Bagasse (SCB) & 0.405 & 0.6318 & 3.83 & 0.091 & 0.9352 & 7.972 & 6.52 \\
\hline
\end{tabular}




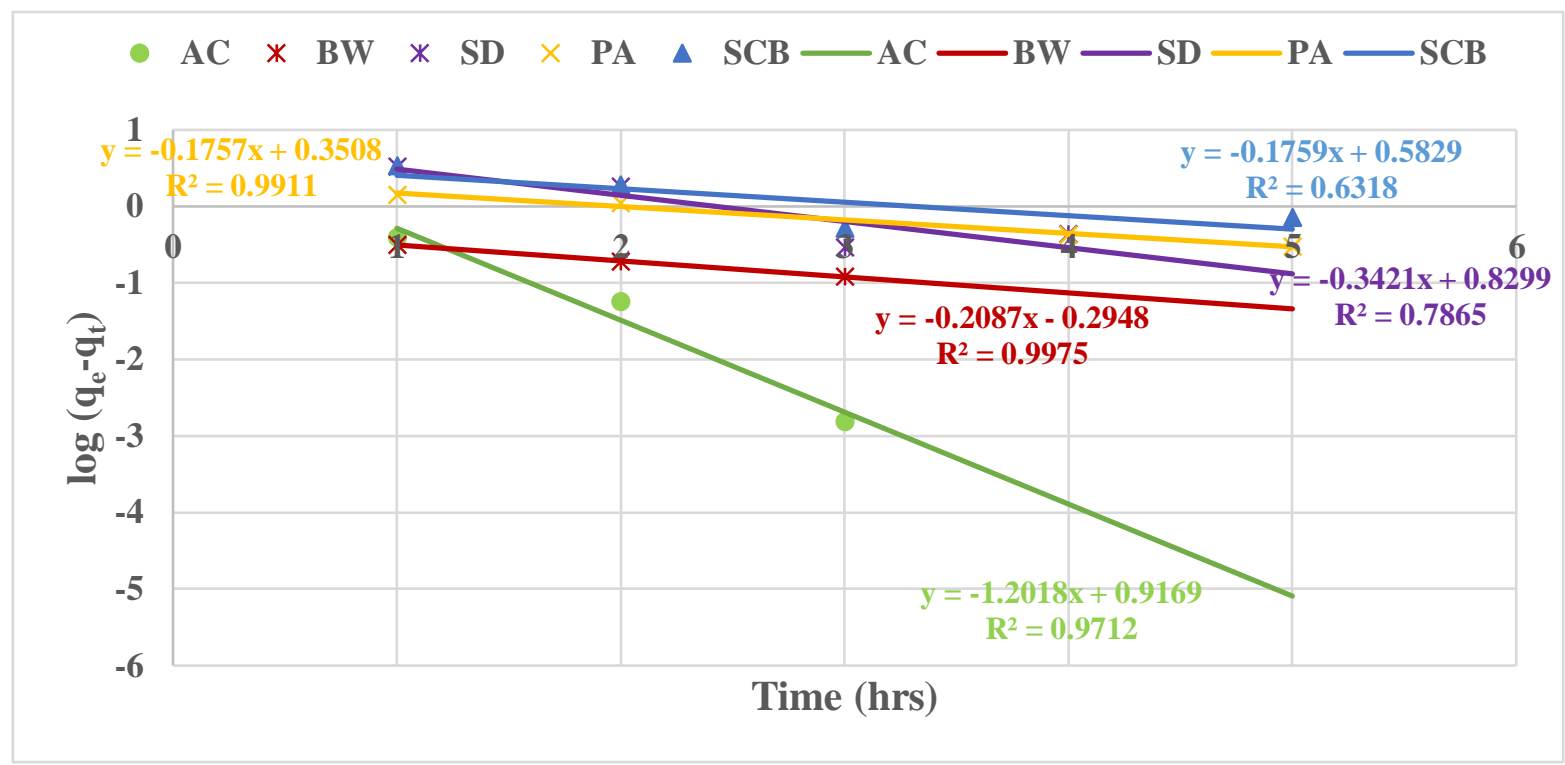

Figure 8: Pseudo-first-order model for different adsorbents

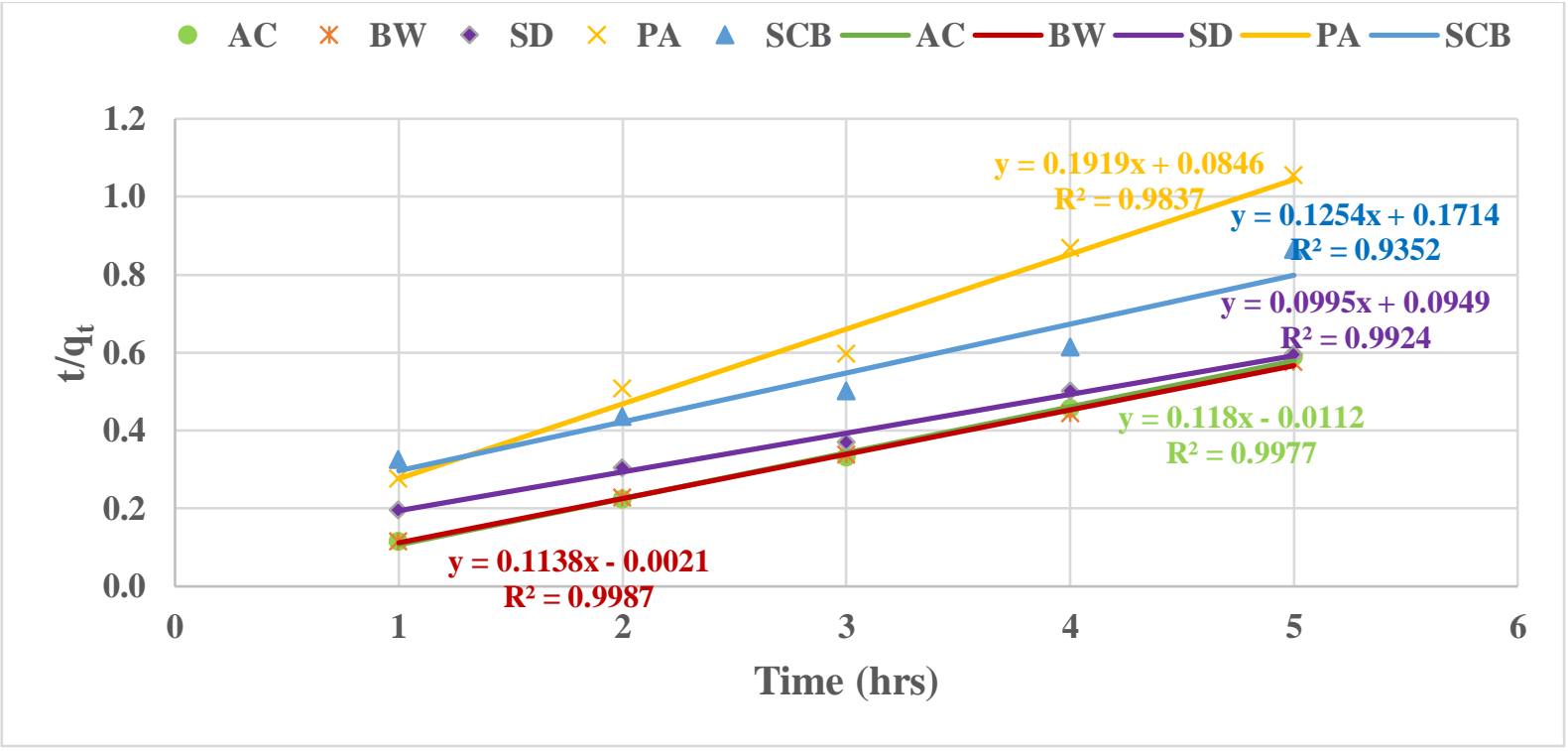

Figure 9: Pseudo-second-order model for different adsorbents

\subsubsection{Langmuir Isotherm}

The isotherm data has been linearized using the Langmuir equation and is plotted between $\mathrm{C}_{\mathrm{e}}$ versus $\mathrm{C}_{\mathrm{e}} / \mathrm{q}_{\mathrm{e}}$ which is shown in Fig. (10)(a),(b) for low concentrations (25-50-100-200) and for high concentrations (400-600-800-1000) respectively. The Langmuir parameters $\mathrm{Q}_{\mathrm{m}}, \mathrm{b}$ and $\mathrm{R}_{\mathrm{L}}$ are estimated for different adsorbents and are given in Table (3). The Langmuir constant $\mathrm{Q}_{\mathrm{m}}$, which is a measure of the monolayer adsorption capacity of the adsorbents, is obtained as 26.20,31.51, 13.02, 19.72 and $13.49 \mathrm{mg} / \mathrm{g}$ for AC, BW, SD, PA and SCB respectively in the equilibrium $\mathrm{pH}$ value of 3 for all adsorbents at low concentrations. At the optimum conditions for the best four materials at high concentration, the increase in $\mathrm{Cr}$ (VI) initial concentration to (400-600-800-1000) $\mathrm{mg} / \mathrm{L}$ increases the monolayer adsorption capacity $\mathrm{Q}_{\mathrm{m}}$ to $105.84,29.86,19.30$ and $73.83 \mathrm{mg} / \mathrm{g}$ for AC, BW, SD, PA and SCB respectively. The increase in adsorption capacity with an increase in the $\mathrm{Cr}(\mathrm{VI})$ concentration may be due to the higher adsorption rate and the utilization of all the active sites available for the adsorption at higher concentration. The Langmuir constant, $b$, which denotes adsorption energy, is found to be $0.0424,0.0301,0.0327$, 0.0076 and $0.0102 \mathrm{~L} / \mathrm{mg}$ at low concentrations for $\mathrm{AC}, \mathrm{BW}$, SD, PA and SCB respectively. Langmuir constant b for low concentration was found $0.0016,0.0122,0.0415$ and 0.0015 for the last four materials respectively. The value of coefficient of correlation $\left(\mathrm{R}^{2}=0.986,0.8614,0.9531,0.7611\right.$ and 0.7747$)$ obtained for AC, BW, SD, PA and SCB at low concentrations do not support the monolayer adsorption of $\mathrm{Cr}$ (VI) onto the different adsorbents except for sawdust which was 0.9531 . On the other hand, it is found that the value of $\mathrm{R}^{2}$ is very close to unit at higher concentrations for BW,SD and SCB which confirms the monolayer adsorption of $\mathrm{Cr}(\mathrm{VI})$ at these adsorbents. 


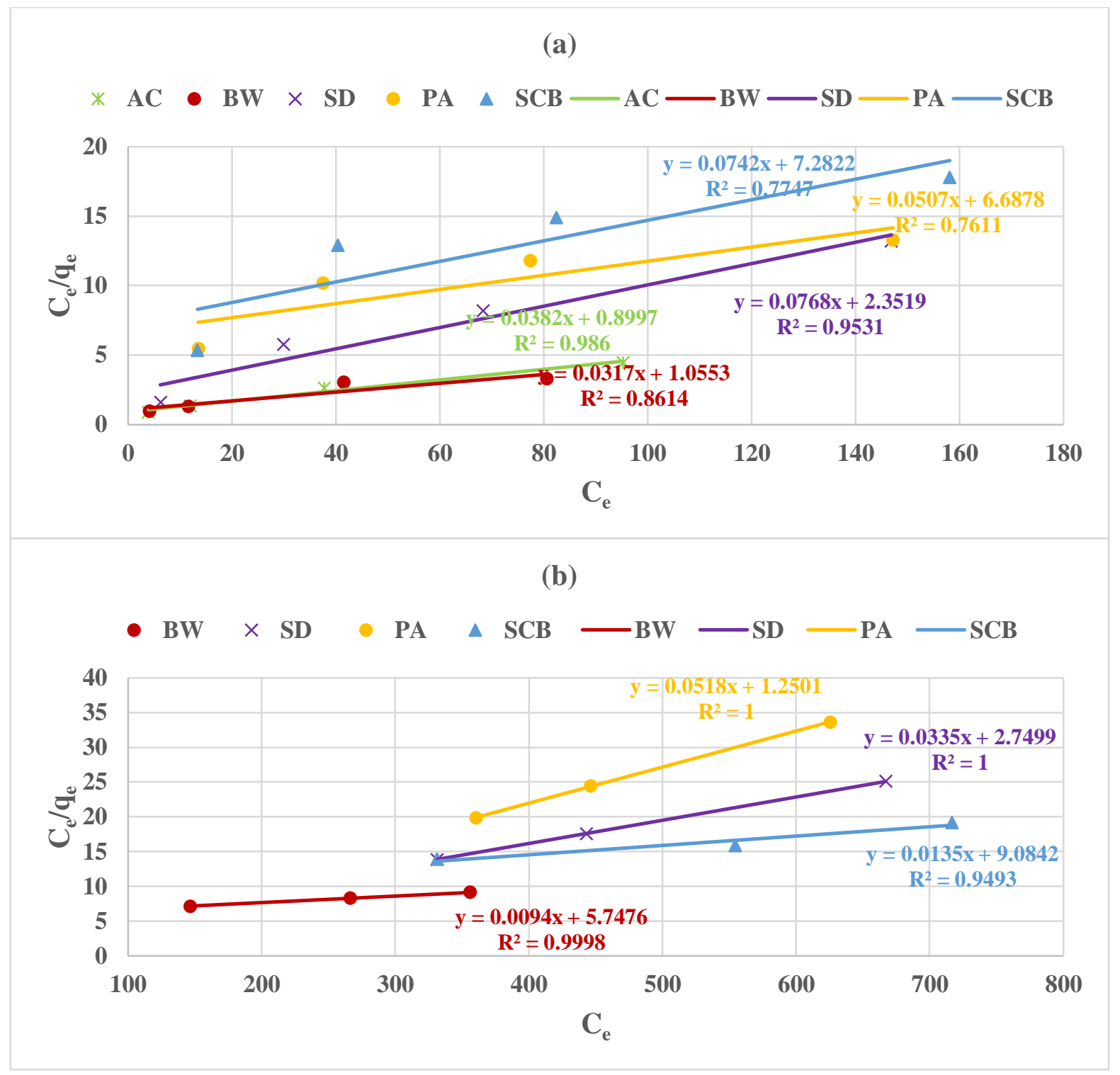

Figure 10: Langmuir isotherm (a) at low conc., (b) at high conc

The dimensionless parameter, $\mathrm{R}_{\mathrm{L}}$, which is a measure of adsorption favorability is found to be in a range of 0.1 to 0.62 $\left(0<\mathrm{R}_{\mathrm{L}}<1\right)$ which confirms the favorable adsorption process for $\mathrm{Cr}$ (VI) removal using different adsorbents. Though the $\mathrm{R}^{2}$ value obtained is very high for some adsorbents, in order to find out if a better fit is possible with other isotherms, the results are analyzed with other two isotherms available in the literature.

\subsubsection{Freundlich Isotherm}

The Freundlich constants, $\mathrm{K}_{\mathrm{f}}(\mathrm{mg} / \mathrm{g})$ and $\mathrm{n}$ are obtained by plotting the graph between $\log \mathrm{q}_{\mathrm{e}}$ versus $\log \mathrm{C}_{\mathrm{e}}$ as shown in Fig. (11) (a), (b) for low concentrations (25-50-100-200) $\mathrm{mg} / \mathrm{L}$ and for high concentrations (400-600-800-1000) $\mathrm{mg} / \mathrm{L}$ respectively. The values of $\mathrm{K}_{\mathrm{f}}$ are 1.46, 1.38, 1.34, 0.70 and 0.78 for $\mathrm{AC}, \mathrm{BW}, \mathrm{SD}, \mathrm{PA}$ and $\mathrm{SCB}$ at low concentrations respectively and $0.77,2.72,3.12$ and 0.88 for the last four adsorbents at high concentrations respectively. The values of $n_{f}$ are $0.49,0.54,0.34,0.63$ and 0.52 for $\mathrm{AC}, \mathrm{BW}, \mathrm{SD}, \mathrm{PA}$ and $\mathrm{SCB}$ at low concentrations respectively and $0.73,0.15,0.05$ and 0.60 for the last four adsorbents at high concentrations respectively. The obtained values of $n_{F}$ are less than 1 for both low and high concentrations which supports the chemisorption phenomena during $\mathrm{Cr}$ (VI) adsorption on all adsorbents at different conditions (52). It is found that the coefficient of correlation obtained from the Freundlich isotherm model for adsorbents ranges from 0.9405 to 0.9988 , which is higher than that for Langmuir isotherm model as given in Table (4). These results support the possibility of heterogeneous adsorption on multi-layers. The obtained result indicates that the equilibrium data is fitted well with the Freundlich isotherm model at low concentrations for all adsorbents except for SD. Similar observations were recorded by (21) when they study the adsorption of $\mathrm{Cr}$ (VI) on Banana Trunk Fibers (BTF) and reinforced Chitosan Bio composite (CTB). 
Table 3: Langmuir parameters for $\mathrm{Cr}$ removal using different adsorbents

\begin{tabular}{|c|c|c|c|c|c|}
\hline At $303{ }^{\circ} \mathrm{K}$ & \multicolumn{5}{|c|}{ Langmuir Constants for low concentrations } \\
\hline Adsorbent & $\begin{array}{l}\text { Maximum monolayer } \\
\text { coverage } \mathrm{mg} / \mathrm{g}\left(\mathrm{Q}_{\mathrm{m}}\right)\end{array}$ & $\begin{array}{l}\text { Langmuir } \\
\text { constant L/mg (b) }\end{array}$ & $\begin{array}{l}\mathrm{R}_{\mathrm{L}} \\
\text { favorable if } \\
0<\mathrm{R}_{\mathrm{L}}<1\end{array}$ & $\begin{array}{l}\mathrm{R}^{2} \\
\text { Best error } \\
\text { distribution }\end{array}$ & $\begin{array}{l}\text { qe (exp.) } \\
\mathrm{mg} / \mathrm{g}\end{array}$ \\
\hline Activated carbon (AC) & 26.20 & 0.0424 & 0.26 & 0.986 & 21.46 \\
\hline Banana waste (BW) & 31.51 & 0.0301 & 0.33 & 0.8614 & 24.38 \\
\hline Sawdust (SD) & 13.02 & 0.0327 & 0.31 & 0.9531 & 11.13 \\
\hline $\begin{array}{l}\text { Phragmites Australis } \\
\text { (PA) }\end{array}$ & 19.72 & 0.0076 & 0.62 & 0.7611 & 11.07 \\
\hline Sugarcane bagasse (SCB) & 13.49 & 0.0102 & 0.56 & 0.7747 & 8.88 \\
\hline At $303^{\circ} \mathrm{K}$ & \multicolumn{5}{|c|}{ Langmuir Constants for high concentrations } \\
\hline Adsorbent & $\begin{array}{l}\text { Maximum monolayer } \\
\text { coverage } \mathrm{mg} / \mathrm{g}\left(\mathrm{Q}_{\mathrm{m}}\right)\end{array}$ & $\begin{array}{l}\text { Langmuir } \\
\text { constant L/mg (b) }\end{array}$ & $\begin{array}{l}\mathrm{R}_{\mathrm{L}} \\
\text { favorable if } \\
0<\mathrm{R}_{\mathrm{L}}<1\end{array}$ & $\begin{array}{l}\mathrm{R}^{2} \\
\text { Best error } \\
\text { distribution }\end{array}$ & qe (exp.) \\
\hline Banana waste (BW) & 105.84 & 0.0016 & 0.43 & 0.9998 & 39.02 \\
\hline Sawdust (SD) & 29.86 & 0.0122 & 0.1 & 1 & 26.58 \\
\hline $\begin{array}{l}\text { Phragmites Australis } \\
\text { (PA) }\end{array}$ & 19.30 & 0.0415 & 0.03 & 1 & 18.59 \\
\hline Sugarcane bagasse (SCB) & 73.83 & 0.0015 & 0.48 & 0.9493 & 37.34 \\
\hline
\end{tabular}

Table 4: Freundlich parameters for Chromium using different adsorbents

\begin{tabular}{|c|c|c|c|}
\hline At $303 \mathrm{oK}$ & \multicolumn{3}{|c|}{ Freundlich Constants for low concentrations } \\
\hline Adsorbent & $\begin{array}{l}\text { Relative adsorption capacity of } \\
\text { adsorbent related to the bonding } \\
\text { energy (KF) }\end{array}$ & $\begin{array}{l}\text { Heterogeneity factor representing the } \\
\text { deviation from linearity of adsorption } \\
(\mathrm{nF})\end{array}$ & $\begin{array}{l}\text { R2 } \\
\text { Best error } \\
\text { distribution }\end{array}$ \\
\hline Activated carbon & 1.46 & 0.49 & 0.9905 \\
\hline Banana waste & 1.38 & 0.54 & 0.9755 \\
\hline Sawdust & 1.34 & 0.34 & 0.9405 \\
\hline Phragmites Australis & 0.70 & 0.63 & 0.9693 \\
\hline Sugarcane bagasse & 0.78 & 0.52 & 0.9200 \\
\hline At $303 \mathrm{oK}$ & \multicolumn{3}{|c|}{ Freundlich Constants for high concentrations } \\
\hline Adsorbent & $\begin{array}{l}\text { Relative adsorption capacity of } \\
\text { adsorbent related to the bonding } \\
\text { energy (KF) }\end{array}$ & $\begin{array}{l}\text { Heterogeneity factor representing the } \\
\text { deviation from linearity of adsorption } \\
(\mathrm{nF})\end{array}$ & $\begin{array}{l}\text { R2 } \\
\text { Best error } \\
\text { distribution }\end{array}$ \\
\hline Banana waste & 0.77 & 0.73 & 0.9988 \\
\hline Sawdust & 2.72 & 0.15 & 0.9891 \\
\hline Phragmites Australis & 3.12 & 0.05 & 0.9950 \\
\hline Sugarcane bagasse & 0.88 & 0.60 & 0.9642 \\
\hline
\end{tabular}




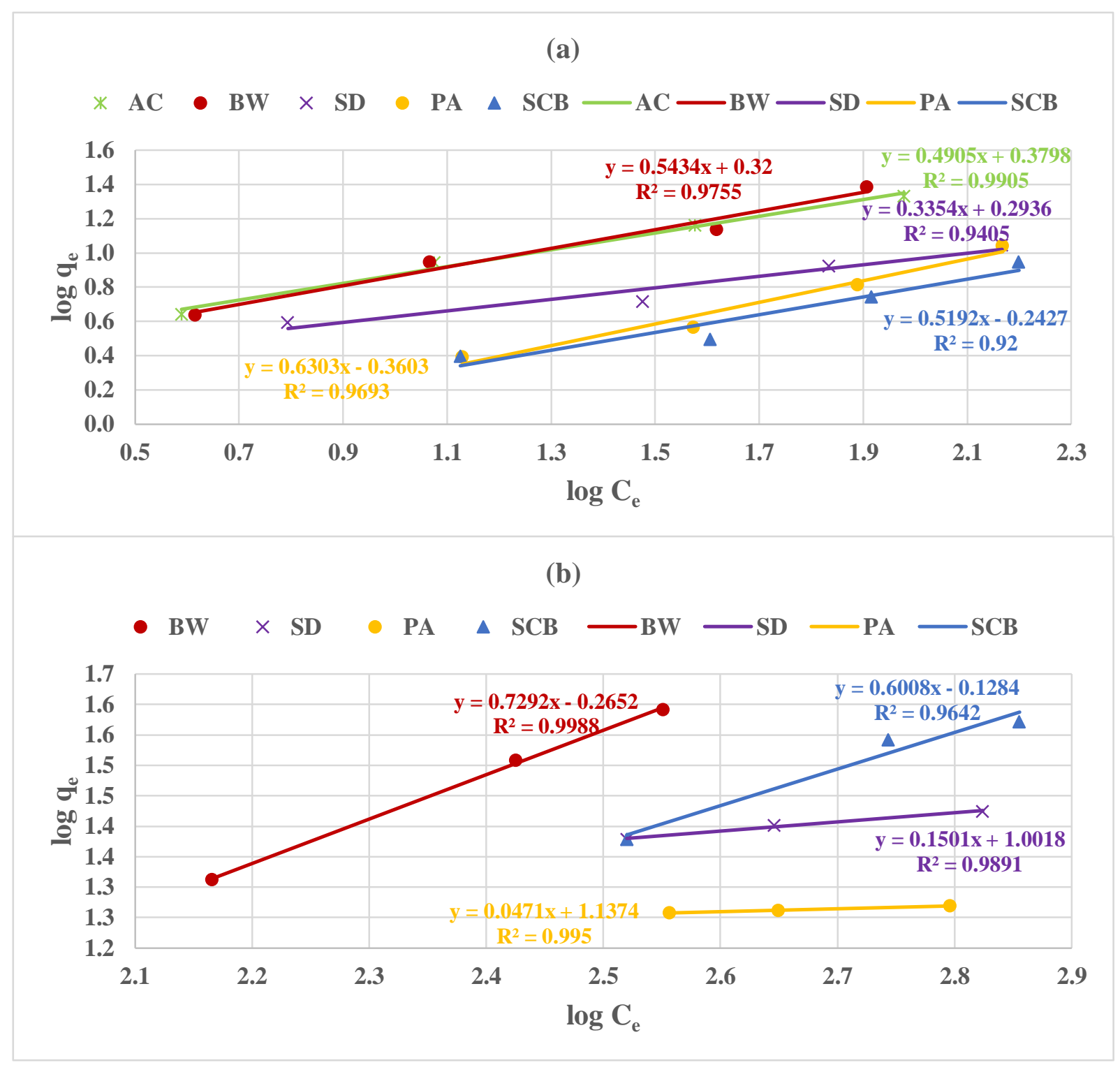

Figure 11: Freundlich isotherm (a) low conc., (b) high conc

\subsubsection{Tempkin Isotherm}

A plot of $\mathrm{q}_{\mathrm{e}}$ versus $\ln \mathrm{C}_{\mathrm{e}}$ at a constant temperature shown in Fig (12) (a), (b) is used to calculate the Tempkin isotherm constants, Ат and bт which are tabulated in Table (5) for low and high concentrations respectively. Tempkin isotherm model takes the adsorbent adsorbate interactions in consideration(53). The constant $\mathrm{A}_{\mathrm{T}}$ obtained from Tempkin isotherm model are $0.51,0.40,0.65,0.11$ and $0.14 \mathrm{~L} / \mathrm{g}$ for $\mathrm{AC}, \mathrm{BW}, \mathrm{SD}, \mathrm{PA}$ and SCB at low concentrations respectively and $0.018,1.69,0.005$ and $0.012 \mathrm{~L} / \mathrm{g}$ for the last four materials at high concentrations respectively. The constant $\mathrm{b}_{\mathrm{T}}$ obtained for Tempkin isotherm model are 478.69, 409.69, 1116.56, 722.30 and 1002.22 for AC, BW, SD, PA and SCB at low concentrations respectively and $121.79,664.25,120.80$ and 140.03 for the last four materials at high concentrations respectively. The obtained coefficient of determination $\left(\mathrm{R}^{2}\right)$ for Tempkin isotherm model ranges from 0.8442 to 0.9982 , which is lower than Langmuir and Freundlich for all adsorbents except for SCB at higher concentrations which was 0.9747 more than the $\mathrm{R}^{2}$ calculated for the other two isotherm models. The summary of the calculated values of regression coefficient $\left(\mathrm{R}^{2}\right)$ and isotherms parameters for the adsorption of $\mathrm{Cr}(\mathrm{VI})$ on $\mathrm{AC}, \mathrm{BW}, \mathrm{SD}, \mathrm{PA}$ and SCB at both low and high concentrations are tabulated in Table (6). From Table (6), it is clear that AC, BW, PA and SCB follow the multi-layer adsorption theory of Freundlich isotherm that gave the highest $\mathrm{R}^{2}$ at low concentrations. While $\mathrm{SD}$ at low concentration besides BW,SD and PA at high concentrations follow the monolayer adsorption of Langmuir isotherm that gave a $\mathrm{R}^{2}$ value near or equal to the unit. Finally SCB at higher concentration is the only adsorbent which fits to Tempkin isotherm with $\mathrm{R}^{2}$ value of 0.9747 . 
Table 5: Tempkin parameters for $\mathrm{Cr}$ removal using different adsorbents

\begin{tabular}{|l|l|l|l|l|}
\hline At $303^{\circ} \mathrm{K}$ & \multicolumn{4}{l|}{ Tempkin Constants for low concentrations } \\
\hline Adsorbent & $\left(\mathrm{A}_{\mathrm{T}}\right)(\mathrm{L} / \mathrm{g})$ & $\left(\mathrm{b}_{\mathrm{T}}\right)$ & $\left(\mathrm{B}_{\mathrm{T}}=\mathrm{RT} / \mathrm{b}_{\mathrm{T}}\right)$ & $\mathrm{R}^{2}$ best error distribution \\
\hline Activated carbon & 0.51 & 478.69 & 5.26 & 0.9799 \\
\hline Banana waste & 0.40 & 409.69 & 6.15 & 0.8933 \\
\hline Sawdust & 0.65 & 1116.56 & 2.26 & 0.8858 \\
\hline Phragmites Australis & 0.11 & 722.30 & 3.49 & 0.8762 \\
\hline Sugarcane bagasse & 0.14 & 1002.22 & 2.51 & 0.8442 \\
\hline At $303^{\circ} \mathrm{K}$ & Tempkin Constants for high concentrations & \multicolumn{2}{|l|}{} \\
\hline Adsorbent & $\left(\mathrm{A}_{\mathrm{T}}\right)(\mathrm{L} / \mathrm{g})$ & $\left(\mathrm{b}_{\mathrm{T}}\right)$ & $\left(\mathrm{B}_{\mathrm{T}}=\mathrm{RT} / \mathrm{b}_{\mathrm{T}}\right)$ & $\mathrm{R}^{2}$ best error distribution \\
\hline Banana waste & 0.018 & 121.79 & 20.67 & 0.9982 \\
\hline Sawdust & 1.69 & 664.25 & 3.79 & 0.9920 \\
\hline Phragmites Australis & 0.005 & 120.80 & 20.84 & 0.9994 \\
\hline Sugarcane bagasse & 0.012 & 140.03 & 17.98 & 0.9747 \\
\hline
\end{tabular}

(a)

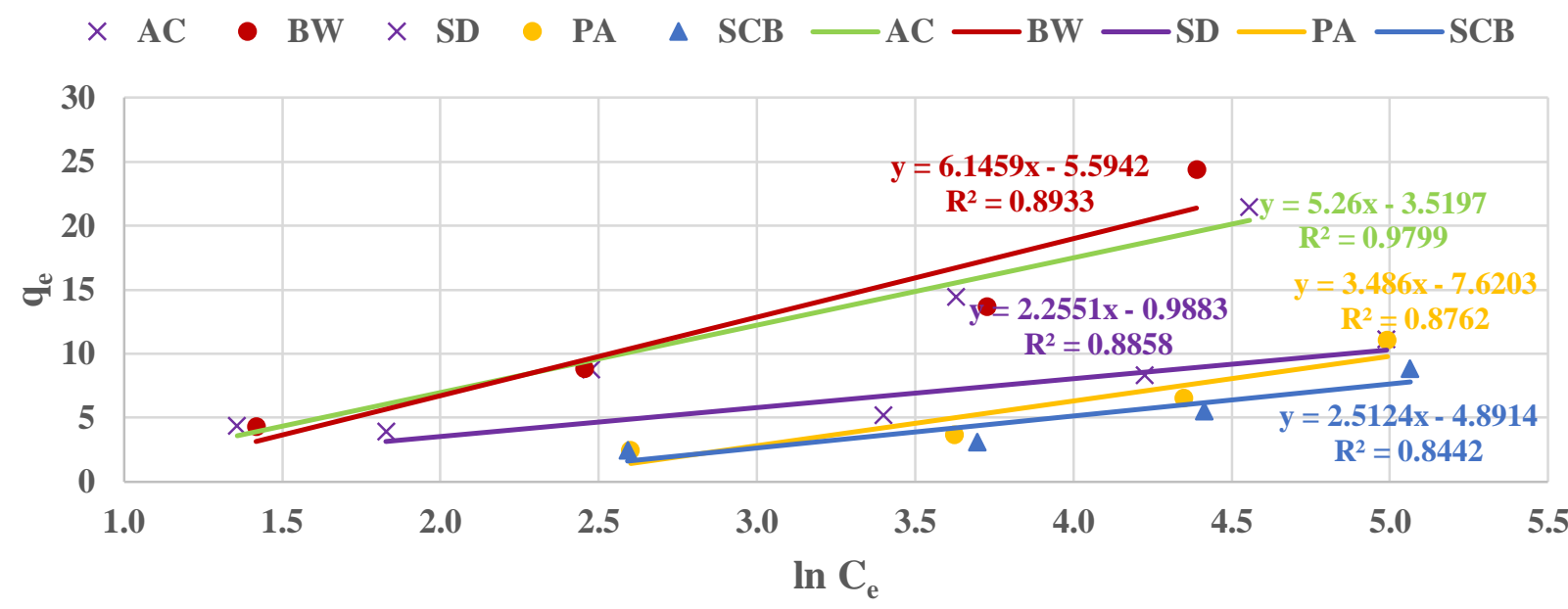

(b)

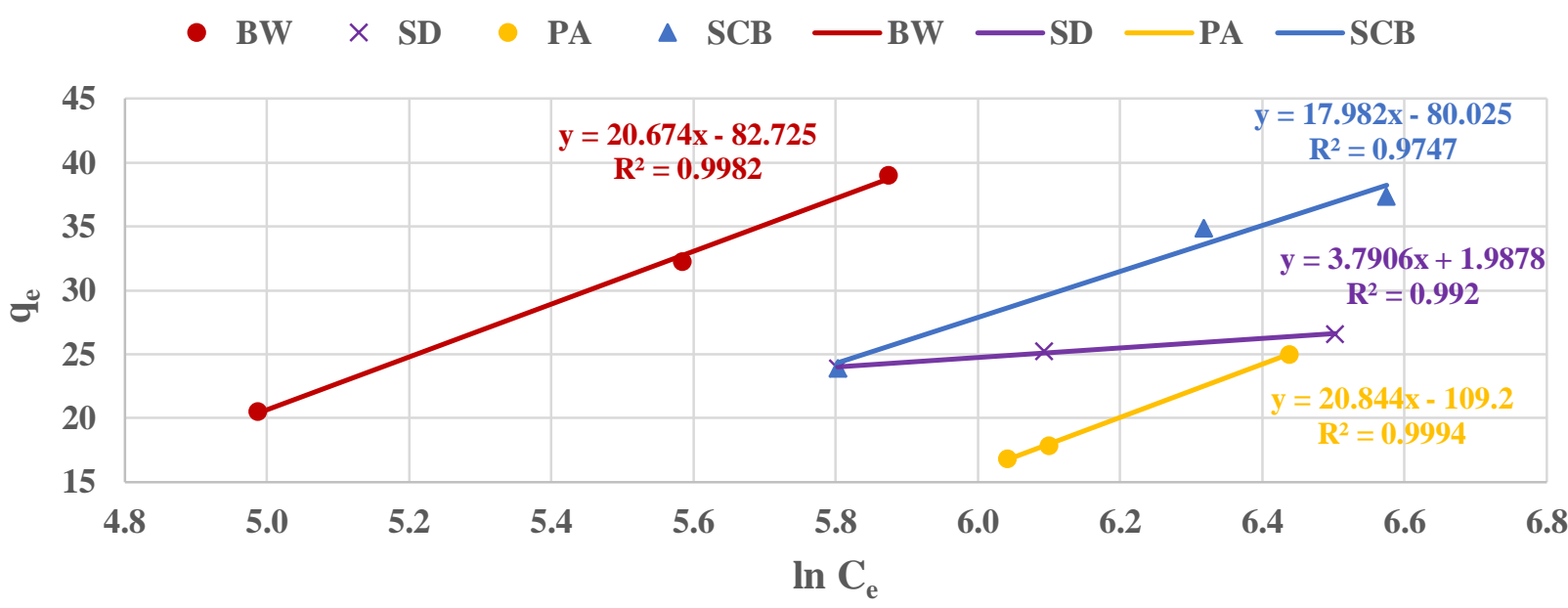

Figure 12: Tempkin isotherm (a) at low conc., (b) at high conc 
Table 6: Summary of isotherms constants for different adsorbents at low and high concentrations

\begin{tabular}{|c|c|c|c|c|c|c|c|c|c|c|c|c|}
\hline \multicolumn{2}{|c|}{ At $303^{\circ} \mathrm{K}$} & \multicolumn{4}{|c|}{ Langmuir Constants } & \multicolumn{3}{|c|}{ Freundlich Constants } & \multicolumn{4}{|c|}{ Tempkin Constants } \\
\hline \multirow{6}{*}{ 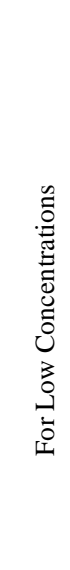 } & Adsorbent & $\mathrm{Q}_{\mathrm{m}}$ & $\mathrm{b}$ & $\mathrm{R}_{\mathrm{L}}$ & $\mathrm{R}^{2}$ & $\mathrm{~K}_{\mathrm{F}}$ & $\mathrm{n}_{\mathrm{F}}$ & $\mathrm{R}^{2}$ & $\mathrm{~A}_{\mathrm{T}}$ & $\mathrm{b}_{\mathrm{T}}$ & $\mathrm{B}_{\mathrm{T}}$ & $\mathrm{R}^{2}$ \\
\hline & $\begin{array}{l}\text { Activated } \\
\text { carbon }\end{array}$ & 26.20 & 0.0424 & 0.26 & 0.986 & 1.46 & 0.49 & 0.9905 & 0.51 & 478.69 & 5.26 & 0.9799 \\
\hline & Banana waste & 31.51 & 0.0301 & 0.33 & 0.8614 & 1.38 & 0.54 & 0.9755 & 0.40 & 409.69 & 6.15 & 0.8933 \\
\hline & Sawdust & 13.02 & 0.0327 & 0.31 & 0.9531 & 1.34 & 0.34 & 0.9405 & 0.65 & 1116.56 & 2.26 & 0.8858 \\
\hline & $\begin{array}{l}\text { Phragmites } \\
\text { Australis }\end{array}$ & 19.72 & 0.0076 & 0.62 & 0.7611 & 0.70 & 0.63 & 0.9693 & 0.11 & 722.30 & 3.49 & 0.8762 \\
\hline & $\begin{array}{l}\text { Sugarcane } \\
\text { bagasse }\end{array}$ & 13.49 & 0.0102 & 0.56 & 0.7747 & 0.78 & 0.52 & 0.9200 & 0.14 & 1002.22 & 2.51 & 0.8442 \\
\hline \multicolumn{2}{|c|}{ At $303{ }^{\circ} \mathrm{K}$} & \multicolumn{4}{|c|}{ Langmuir Constants } & \multicolumn{3}{|c|}{ Freundlich Constants } & \multicolumn{4}{|c|}{ Tempkin Constants } \\
\hline \multirow{5}{*}{ 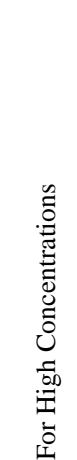 } & Adsorbent & $\mathrm{Q}_{\mathrm{m}}$ & $\mathrm{b}$ & $\mathrm{R}_{\mathrm{L}}$ & $\mathrm{R}^{2}$ & $\mathrm{~K}_{\mathrm{F}}$ & $\mathrm{n}_{\mathrm{F}}$ & $\mathrm{R}^{2}$ & $\mathrm{~A}_{\mathrm{T}}$ & $\mathrm{b}_{\mathrm{T}}$ & $\mathrm{B}_{\mathrm{T}}$ & $\mathrm{R}^{2}$ \\
\hline & Banana waste & 105.84 & 0.0016 & 0.43 & 0.9998 & 0.77 & 0.73 & 0.9988 & 0.018 & 121.79 & 20.67 & 0.9982 \\
\hline & Sawdust & 29.86 & 0.0122 & 0.1 & 1 & 2.72 & 0.15 & 0.9891 & 1.69 & 664.25 & 3.79 & 0.9920 \\
\hline & $\begin{array}{l}\text { Phragmites } \\
\text { Australis }\end{array}$ & 19.30 & 0.0415 & 0.03 & 1 & 3.12 & 0.05 & 0.9950 & 0.005 & 120.80 & 20.84 & 0.9994 \\
\hline & $\begin{array}{l}\text { Sugarcane } \\
\text { bagasse }\end{array}$ & 73.83 & 0.0015 & 0.48 & 0.9493 & 0.88 & 0.60 & 0.9642 & 0.012 & 140.03 & 17.98 & 0.9747 \\
\hline
\end{tabular}

\section{Conclusions}

The study reveals that BW and SD are the best adsorbents for the removal of $\mathrm{Cr}$ (VI) from industrial wastewater for both low and high concentrations. At higher concentration of 1000 $\mathrm{mg} / \mathrm{L}$, (BW) gives the best removal efficiency of about $73 \%$ using $25 \mathrm{gm} / \mathrm{L}$ dosage, $\mathrm{pH}=3$ and 3 hours contact time. The maximum adsorption capacity of $86 \mathrm{mg} / \mathrm{g}$ at $1000 \mathrm{mg} / \mathrm{L}$ was obtained for (SD) at its optimum conditions. Preparation and treatment method has a vital effect on the adsorption characteristics for each adsorbent. BW treated with $\mathrm{HCl}$ only shows the best results while other adsorbents give highest removal efficiencies when treated with acid-alkali treatment. The Chromium adsorption capacity of all the investigated materials is highly dependent on $\mathrm{pH}$ and achieves high efficiency at low $\mathrm{pH} 2-3$. The Chromium adsorption capacity is highly dependent on dosage, initial concentration, contact time and temperature. In the present study, all adsorbents follow Pseudo-second-order kinetic model with high regression coefficient. The equilibrium isotherm data for AC, BW, PA and SCB at low concentrations were best fitted to Freundlich isotherm while SD at low concentrations and $\mathrm{BW}, \mathrm{SD}$ and $\mathrm{PA}$ at higher concentrations were following Langmuir isotherm. $\mathrm{SCB}$ at high concentrations is the only adsorbent fitted to Tempkin isotherm.

\section{Ethical issue}

Authors are aware of, and comply with, best practice in publication ethics specifically with regard to authorship (avoidance of guest authorship), dual submission, manipulation of figures, competing interests and compliance with policies on research ethics. Authors adhere to publication requirements that submitted work is original and has not been published elsewhere in any language.

\section{Competing interests}

The authors declare that there is no conflict of interest that would prejudice the impartiality of this scientific work.

\section{Authors' contribution}

All authors of this study have a complete contribution for data collection, data analyses and manuscript writing.

\section{References}

1. Meroufel B, Zenasni MA, George B. Valorisation and modification of saharan clay for removal of $\mathrm{Cu}(\mathrm{II}), \mathrm{Ni}(\mathrm{II}), \mathrm{Co}(\mathrm{II})$ and $\mathrm{Cd}(\mathrm{II})$ from aqueous solutions. Polish J Environ Stud. 2020;29(2):1287-92.

2. Kamal El Dean AM, Hashem EY, Ahmed MM, Mohamed MA Hussain SM. Removal of chromium(VI) from wastewater using citric acid modified sugarcane bagasse. Eur Chem Bull. 2019;8(5):141-9.

3. Zhou J, Chen H, Thring RW, Arocena JM. Chemical Pretreatment of Rice Straw Biochar: Effect on Biochar Properties and Hexavalent 
Chromium Adsorption. Int J Environ Res [Internet]. 2019;13(1):91105. Available from: https://doi.org/10.1007/s41742-018-0156-1

4. Shakya A. Green Pea Pod Biochar as a Low-Cost Adsorbent: An Alternative Approach for the Removal of $\mathrm{Cr}$ (VI) from Aqueous Solution. Int J Pure Appl Biosci. 2018;6(4):375-86.

5. Gunatilake SK. Removal of Cr ( III ) Ions from Wastewater using Sawdust and Rice Husk Biochar Pyrolyzed at Low Temperature. 2017;(May).

6. Gupta S, Babu B V. Removal of toxic metal $\mathrm{Cr}(\mathrm{VI})$ from aqueous solutions using sawdust as adsorbent: Equilibrium, kinetics and regeneration studies. Chem Eng J. 2009;150(2-3):352-65.

7. Ullah R, Ahmad W, Ahmad I, Khan M, Iqbal Khattak M, Hussain F. Adsorption and recovery of hexavalent chromium from tannery wastewater over magnetic max phase composite. Sep Sci Technol [Internet]. 2020;00(00):1-14. Available from: https://doi.org/10.1080/01496395.2020.1717531

8. Ihsanullah, Abbas A, Al-Amer AM, Laoui T, Al-Marri MJ, Nasser MS, et al. Heavy metal removal from aqueous solution by advanced carbon nanotubes: Critical review of adsorption applications. Sep Purif Technol. 2016;157:141-61.

9. Chakraborty R, Verma R, Asthana A, Vidya SS, Singh AK. Adsorption of hazardous chromium (VI) ions from aqueous solutions using modified sawdust: kinetics, isotherm and thermodynamic modelling. Int J Environ Anal Chem [Internet]. 2019;00(00):1-18. Available from: https://doi.org/10.1080/03067319.2019.1673743

10. Suseno Ahmad, Wijaya K, Trisunayati.W S. Ournal of. Asian J Chem 2016;28(2):347-50

11. Minas F, Chandravanshi BS, Leta S. Chemical precipitation method for chromium removal and its recovery from tannery wastewater in Ethiopia. Chem Int. 2017;3(May):291-305.

12. Bedemo A, Chandravanshi BS, Zewge F. Removal of trivalent chromium from aqueous solution using aluminum oxide hydroxide. Springerplus. 2016;5(1)

13. Pathak PD, Mandavgane SA, Kulkarni BD. Fruit peel waste as a novel low-cost bio adsorbent. Rev Chem Eng. 2015;31(4):361-81.

14. Yogeshwaran V, Priya AK. Removal of Hexavalent Chromium (Cr6 ) Using Different Natural Adsorbents - A Review. Ssrn. 2017;8(6):611.

15. Devi B, Jahagirdar A, Ahmed M. Adsorption of Chromium on Activated Carbon Prepared from Coconut Shell. Adsorption [Internet]. 2012;2(5):364-70 Available from: http://www.academia.edu/download/30843873/BJ25364370.pdf

16. Sharma PK, Ayub S, Tripathi CN. Isotherms describing physical adsorption of $\mathrm{Cr}(\mathrm{VI})$ from aqueous solution using various agricultural wastes as adsorbents. Cogent Eng [Internet]. 2016;3(1). Available from: http://dx.doi.org/10.1080/23311916.2016.1186857

17. Prastuti OP, Septiani EL, Kurniati Y, Widiyastuti, Setyawan H. Banana peel activated carbon in removal of dyes and metals ion in textile industrial waste. Mater Sci Forum. 2019;966 MSF:204-9.

18. Mondal NK, Samanta A, Chakraborty S, Shaikh WA. Enhanced chromium(VI) removal using banana peel dust: isotherms, kinetics and thermodynamics study. Sustain Water Resour Manag. 2018;4(3):48997.

19. Ali A, Saeed K, Mabood F. Removal of chromium (VI) from aqueous medium using chemically modified banana peels as efficient low-cost adsorbent. Alexandria Eng J [Internet]. 2016;55(3):2933-42. Available from: http://dx.doi.org/10.1016/j.aej.2016.05.011

20. Sharma PK, Ayub S, Tripathi CN. Isotherms describing physical adsorption of $\mathrm{Cr}(\mathrm{VI})$ from aqueous solution using various agricultural wastes as adsorbents. Cogent Eng [Internet]. 2016;3(1):1-20. Available from: http://dx.doi.org/10.1080/23311916.2016.1186857

21. Rahim M, Mas Haris MRH. Chromium (VI) removal from neutral aqueous media using banana trunk fibers (BTF)-reinforced chitosanbased film, in comparison with BTF, chitosan, chitin and activated carbon. SN Appl Sci [Internet]. 2019;1(10):1-11. Available from: https://doi.org/10.1007/s42452-019-1206-9

22. Ng ZG, Lim JW, Isa MH, Pasupuleti VR, Yunus NM, Lee KC. Adsorptive removal of hexavalent chromium using sawdust Enhancement of biosorption and bioreduction. Sep Sci Technol [Internet]. 2017;52(10):1707-16. Available from: https://doi.org/10.1080/01496395.2017.1296868

23. Gunatilake SK. Removal of Cr ( III ) Ions from Wastewater using Sawdust and Rice Husk Biochar Pyrolyzed at Low Temperature. Int J Innov Educ Res. 2016;4(4):44-54.
24. Gupta VK, Mohan D, Sharma S, Park KUKT. Removal of chromium ( VI ) from electroplating industry wastewater using bagasse fly ash a sugar industry waste material. 1999;

25. SINGH SK. REMOVAL OF HEXAVALENT CHROMIUM Cr (VI) BY USING SUGARCANE BAGASSE AS AN LOW COST ADSORBENT. Indian J Sci Res. 2017;13(1):73-6.

26. Kumari P. Application of Sugarcane Bagasse for the Removal of Chromium ( Vi ) and Zinc ( Ii ) From Aqueous Solution. Int Res J Eng Technol. 2017;04:1670-3.

27. Sivakumar D, Shankar D, Mahalakshmi R, Deepalakshmi K. Kinetic Model Studies on Removal of Hexavalent Chromium-Sugarcane Bagasse Powder. Int Res J Multidiscip Sci Technol. 2017;2(5):37-43.

28. Bashir S, Hussain Q, Akmal M, Riaz M, Hu H, Ijaz SS, et al. Sugarcane bagasse-derived biochar reduces the cadmium and chromium bioavailability to mash bean and enhances the microbial activity in contaminated soil. J Soils Sediments. 2018;18(3):874-86.

29. Karri RR, Sahu JN, Meikap BC. Improving efficacy of $\mathrm{Cr}$ (VI) adsorption process on sustainable adsorbent derived from waste biomass (sugarcane bagasse) with help of ant colony optimization. Ind Crops Prod [Internet]. 2020;143(June 2019):111927. Available from: https://doi.org/10.1016/j.indcrop.2019.111927

30. Bahadur KD, Paramatma M. Adsorptive removal of Cr( VI ) from aqueous solution by sugarcane biomass. Res J Chem Sci. 2014;4(5):32-40

31. Shahawy A El. RSC Advances dissolved solids by environmentally friendly and economical dried Phragmites australis $\uparrow$. 2018;40511-28.

32. García-Valero A, Martínez-Martínez S, Faz Á, Terrero MA, Muñoz MÁ, Gómez-López MD, et al. Treatment of wastewater from the tannery industry in a constructed wetland planted with phragmites australis. Agronomy. 2020;10(2):1-15.

33. Mousa WM, Soliman SI, Shier HA. Removal of some Heavy Metals from Aqueous Solution Using Rice Straw. 2013;9(3):1696-701.

34. Brahmaiah T, Spurthi L, Chandrika K, Ramanaiah S, Prasad KSS KINETICS OF HEAVY METAL ( $\mathrm{Cr} \& \mathrm{Ni}$ ) REMOVAL FROM THE WASTEWATER BY USEING LOW COST ADSORBENT. 2015;4(11):1600-10.

35. Hegazi HA. Removal of heavy metals from wastewater using agricultural and industrial wastes as adsorbents. HBRC J [Internet]. 2013;9(3):276-82. Available from: http://dx.doi.org/10.1016/j.hbrcj.2013.08.004

36. Elmolla ES, Hamdy W, Kassem A, Abdel Hady A. Comparison of different rice straw based adsorbents for chromium removal from aqueous solutions. Desalin Water Treat. 2016;57(15):6991-9.

37. Ioannidou O, Zabaniotou A. Agricultural residues as precursors for activated carbon production-A review. Renew Sustain Energy Rev. 2007;11(9):1966-2005

38. Valentín-Reyes J, García-Reyes RB, García-González A, SotoRegalado E, Cerino-Córdova F. Adsorption mechanisms of hexavalent chromium from aqueous solutions on modified activated carbons. J Environ Manage. 2019 Apr 15;236:815-22.

39. Giraldo-Gutiérrez L, Moreno-Piraján JC. $\mathrm{Pb}(\mathrm{II})$ and $\mathrm{Cr}(\mathrm{VI})$ adsorption from aqueous solution on activated carbons obtained from sugar cane husk and sawdust. J Anal Appl Pyrolysis. 2008;81(2):278-84.

40. Mohan D, Pittman CU. Activated carbons and low cost adsorbents for remediation of tri- and hexavalent chromium from water. J Hazard Mater. 2006;137(2):762-811.

41. Kumar A, Jena HM. Adsorption of Cr(VI) from aqueous phase by high surface area activated carbon prepared by chemical activation with ZnCl2. Process Saf Environ Prot [Internet]. 2017;109(Vi):63-71. Available from: http://dx.doi.org/10.1016/j.psep.2017.03.032

42. AL-Othman ZA, Ali R, Naushad M. Hexavalent chromium removal from aqueous medium by activated carbon prepared from peanut shell: Adsorption kinetics, equilibrium and thermodynamic studies. Chem Eng J [Internet]. 2012;184:238-47. Available from: http://dx.doi.org/10.1016/j.cej.2012.01.048

43. Brahmaiah T, Spurthi L, Chandrika K, Ramanaiah S, Sai Prasad KS. Kinetics of heavy metal $(\mathrm{Cr} \& \mathrm{Ni})$ removal from the wastewater by using low cost adsorbent. Prasad al World J Pharm Pharm Sci. 2015;4(11):1600-10

44. Bernard E, Jimoh A, Odigure JO. Heavy Metals Removal from Industrial Wastewater by Activated Carbon Prepared from Coconut Shell. 2013;3(8):3-9

45. Nigam M, Rajoriya S, Rani Singh S, Kumar P. Adsorption of Cr (VI) ion from tannery wastewater on tea waste: Kinetics, equilibrium and 
thermodynamics studies. J Environ Chem Eng [Internet]. 2019;7(3):103188 Available

from:

https://doi.org/10.1016/j.jece.2019.103188

46. Abdel OE, Reiad NA, Elshafei MM. A study of the removal characteristics of heavy metals from wastewater by low-cost adsorbents. J Adv Res [Internet]. 2011;2(4):297-303. Available from: http://dx.doi.org/10.1016/j.jare.2011.01.008

47. Migahed F, Abdelrazak A, Fawzy G. Batch and continuous removal of heavy metals from industrial effluents using microbial consortia. Int J Environ Sci Technol. 2017;14(6):1169-80.

48. Amin MT, Alazba AA, Shafiq M. Adsorptive Removal of Reactive Black 5 from Wastewater Using Bentonite Clay: Isotherms, Kinetics and Thermodynamics. 2015;15302-18.

49. Ingole RS, Lataye DH, Dhorabe PT. Adsorption of phenol onto Banana Peels Activated Carbon. KSCE J Civ Eng. 2017;21(1):100-10.
50. Tang $\mathrm{C}$, Zhang $\mathrm{R}$, Wen $\mathrm{S}$, Li $\mathrm{K}$, Zheng $\mathrm{X}$, Zhu M. Adsorption of Hexavalent Chromium from Aqueous Solution on Raw and Modified Activated Carbon. Water Environ Res. 2009;81(7):728-34.

51. Maheshwari U, Gupta S. Removal of $\mathrm{Cr}(\mathrm{VI})$ from wastewater using activated neem bark in a fixed-bed column: interference of other ion and kinetic modelling studies. Desalin Water Treat [Internet]. 2016;57(18):8514-25. Available from: http://dx.doi.org/10.1080/19443994.2015.1030709

52. Maheshwari U, Gupta S. Removal of Cr(VI) from wastewater using activated neem bark in a fixed-bed column: interference of other ions and kinetic modelling studies. Desalin Water Treat. 2016;57(18):8514 25.

53. Foo KY, Hameed BH. Insights into the modeling of adsorption isotherm systems. Chem Eng J. 2010;156(1):2-10. 